\title{
ANDREW JACKSON AND PRESIDENTIAL POWER
}

\author{
John Yoo*
}

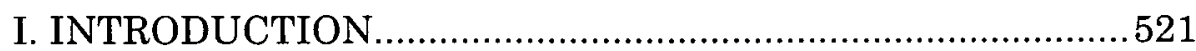

II. THE INVASION OF FLORIDA .......................................526

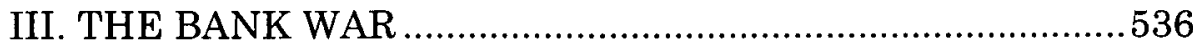

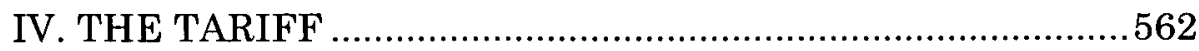

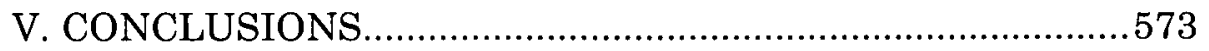

\section{INTRODUCTION}

While Andrew Jackson laid the foundations for what we can begin to recognize as the modern presidency, he would have been out of place in the modern world. He fought duels, owned slaves, and killed Indians (as well as British spies). He carried a lifelong hatred of Great Britain because, as a captured boy soldier during the Revolutionary War, he was struck in the face with a sword for refusing to clean a British officer's boots. During the War of 1812 , he won a resounding victory over the British at the Battle of New Orleans. During the peace, Jackson invaded and occupied Spanish Florida without clear orders. His views on slavery and on Indians would be deemed more than just politically incorrect today. When he lost the election of 1824 despite winning the most votes, Jackson did not graciously withdraw but spent the next four years attacking the "corrupt bargain" that had thrown the Presidency to John Quincy Adams.1

* Professor of Law, University of California at Berkeley School of Law Boalt Hall); Visiting Scholar, American Enterprise Institute. I thank Jesse Choper, Robert Delahunty, Sai Prakash, and Gary Schmitt for their comments. Claire Yan provided excellent research assistance.

1. I have drawn on the wealth of Jackson histories in writing this Article. Jackson's larger than life personality has made him the subject of several 
Upon winning the election of 1828 , Jackson embarked on a transformation of the political system and the Presidency. $\mathrm{He}$ sought to advance the cause of democracy, and made an expanded executive power his tool in that great project. To Jackson, democracy meant that the will of the majority should prevail, regardless of existing governmental and social arrangements. Even Jefferson had not gone that far. The Framers designed a government to check and balance majority rule with the Senate, the Electoral College, and an independent judiciary. Jackson followed a different star. "[T]he first principle of our system," Jackson declared in his State of the Union Address, is "that the majority is to govern." $2 \mathrm{He}$ called for a constitutional amendment to eliminate the Electoral College because " $[t]$ o the people belongs the right of electing their Chief Magistrate." 3 The more elected representatives there were, he observed, the more likely the popular will would be frustrated.4 Jackson remains one of the greatest Presidents because he reconstructed the office into the direct representative of the American people. 5

It does not take a political genius to discover how Jackson

excellent works. Our generation's leading Jackson biographer, Robert V. Remini, provides great detail on Jackson's life in three volumes. ROBERT V. REMINI, ANDREW JACKSON (1977-84) [hereinafter REMINI, JACKSON]. Other helpful works include GERARD N. MAGLIOCCA, ANDREW JACKSON AND THE Constitution: The Rise and Fall of Generational Regimes (2007); H.W. BRANDS, ANDREW JACKSON: His LifE AND TIMES (2006); SEAN WilENTZ, ANDREW JaCKSON (2005); Donald B. Cole, The PresidenCy of ANDREW JaCKSON (1993). Our leading history of the Jackson period is DANIEL WALKER HowE, WHAT HATH God Wrought: The Transformation OF AMERICA 1815-1848 (2007). Older works, such as ARTHUR M. Schlesinger, JR., The AgE of JACKSON (1945), are less helpful in portraying Jackson as a proto-FDR and Jacksonian Democracy as a precursor for the New Deal.

2. Andrew Jackson, First Annual Message to Congress (Dec. 8, 1829), in 2 MEssages AND PaPers OF THE PResidents, 1789-1897, at 448 (James D. Richardson ed., 1896) [hereinafter Jackson, First Annual Message to Congress].

3. Id. at 447 .

4. Id.

5. See Robert V. Remini, The Constitution and the Presidencies: The Jackson Era, in The Constitution AND the AMERICAN PResidency 29 (Martin L. Fausold \& Alan Shank eds., 1991). 
arrived at this view. In the election of 1824, Jackson believed he was the people's choice. He received a plurality of the popular vote, 153,000 out of 361,000 , and of the electoral vote, 99 out of the 131 needed to win. The Constitution threw the election into the House of Representatives, where Henry Clay, who had come in fourth, was Speaker of the House. Clay influenced the House to choose John Quincy Adams, who had received eighty-four electoral votes. Adams picked Clay to be Secretary of State, the position then seen as the stepping-stone to the Presidency. Jackson devoted the next four years to attacking the corruption of the political system, and successfully undermined the legitimacy of the Adams Administration. He became the symbol of a rising democracy, which he promoted once he became President.

The two causes-democratization and expanding the Presidency-were linked, though they need not have been. Democracy was on the rise before Jackson reached office. By the election of 1824 , all but three states had granted the franchise to all white adult males. Most state governors, judges, and officials were elected. While large segments of the population could not vote, such as women and minorities, the United States had achieved a high level of democracy for its time. The workings of the Electoral College would not stand long in the way of majority rule.

The Presidency, by contrast, had declined sharply since Jefferson. Beginning with James Madison in 1808, the Republican members of Congress selected their party's presidential nominee. When the Federalists disappeared after the end of the War of 1812, "King Caucus" effectively selected the nation's President-the very result the Framers' wanted to avoid by creating the Electoral College. Cabinet agencies and their secretaries felt the pull of competing allegiances with the emergence of congressional committees during this period. It became more common for cabinet members to pursue their own agendas, in cooperation with Congress, and for presidents to see themselves more as prime ministers holding together a coalition.

Presidential weakness was displayed in the two great 
challenges of this "Era of Good Feelings." The dominant issue of the early republic, the struggle for dominance between Britain and France, ended when Congress declared war on Britain in 1812. A more dangerous war could not have been risked. America took on the only country with a navy that could actually project force against the East Coast. Congress had continued Jefferson's program of slashing defense spending, leaving the nation without any trained navy or army, while attempting to coerce Britain and France to accept free trade. Incompetent commanders led an invasion of Canada, which failed miserably (to the long-run benefit of both nations). Troops paid for by the private sector fled at the sight of the British army outside Washington, D.C. The nation's capital was captured and burned to the ground. The fleeing President and his family rode unescorted through the Virginia countryside. New England met in convention to consider secession and Massachusetts even sent out independent peace feelers. Had peace not broken out in Europe, Great Britain might well have finished off the United States on the battlefield and perhaps succeeded in splitting New England from the rest of the country. Madison's conception of a small Presidency led him to accept congressional initiative in war and national security, first by allowing Congress to force the nation into war, then by allowing Congress to wage it on the cheap. Starting the war was primarily Congress's fault, but Madison shared in the blame by not stopping it.

The other great antebellum issue was slavery. The Louisiana Purchase meant that slavery remained at the forefront of American politics. Jackson's victory at New Orleans guaranteed that American expansion would continue without interference from Great Britain. Adding territory called upon the national government to decide whether to permit slavery in the new territories. North and South played a delicate balancing game over the admission of new states. Here again, Presidents were noticeable for their absence. President Monroe played no significant role in setting a national agenda for solving the slavery question. Instead, leaders in Congress took the initiative in the 1820 Missouri Compromise, which prohibited slavery in 
the Louisiana Territory north of Missouri. In Congress, the Great Triumvirate of Clay, Daniel Webster, and John Calhoun exercised commanding leadership over the Republican Party. Presidents like Madison, Monroe, and Adams, who owed their nominations to the congressional caucus, had little political leverage to influence the slavery debate.

As presidential power came into doubt, so too did the authority of the national government. Signs of regional separatism had first begun to emerge during Jefferson's embargo and Madison's War. Although the disappearance of the Federalists led to a single dominant political party, regional divisions occurred over tariff levels on imports and federal support for "internal improvements," such as roads and canals. The South, for example, exported raw materials and agricultural products for income and imported finished goods; high tariffs appeared to benefit Northern manufacturers while raising the South's costs. Internal improvements, which included the Erie Canal and interstate roads, created a different set of regional alliances between westerners who favored its benefits for expansion and Eastern States that benefited from increasing economic links with the West. Slavery exacerbated these centrifugal forces, as did increasing democratization, which broke down traditional social and political hierarchies.

Jackson swam against both tides. He reinvigorated the Presidency and is generally considered by historians to have been one of the nation's most vigorous and powerful chief executives. He advanced a new vision of the President as the direct representative of the people. Jackson put theory into practice with the vigorous exercise of his executive powers-interpreting the Constitution and enforcing the law independently, wielding the veto power for policy as well as constitutional reasons, and re-establishing control over the executive branch. In the first of two great political conflicts of his time, the Bank War, Jackson vetoed a law that the Supreme Court and Congress both thought constitutional, removed federal deposits from the Bank, and fired cabinet secretaries who would not carry out his orders. In the second, the Nullification Crisis, Jackson again interpreted the 
nature of the Constitution and the Union on behalf of the people, and made clear his authority to carry out federal law, even against resisting states. Although he was a staunch defender of limited government, Jackson would confront head-on the forces seeking a weaker union or a weaker Executive. His achievement would be to restore and expand the Presidency, within the context of a permanent Union. He would also spark resistance so strong that it would coalesce into a new political party, the Whig party, devoted to opposing concentrated executive power.

\section{THE INVASION OF FLORIDA}

An enduring image of Andrew Jackson is the cartoon of "King Andrew the First," as his critics called him, sitting on a throne after his veto of the Bank. ${ }^{6}$ His war against the Bank, waged using the veto and removal powers, produced more than caricatures. Both his critics and his supporters realized that Jackson was exercising the powers of the Presidency in unprecedented ways. It led to congressional investigations, legislative proposals to rein in the Executive-even the censure of President Jackson by the Senate. Jackson, however, persevered and eventually prevailed. He similarly turned presidential powers to new directions when he overcame South Carolina's threats to nullify federal tariff laws. Throughout, Jackson's belief that he represented the will of the majority infused his conduct of the office of President. He re-energized the Presidency by marrying its constitutional powers to a theory of the Executive as the focal point for national majority rule, a role that was not obvious, to say the least, from the constitutional text.

Jackson's attitude became clear even before he won the job of chief executive. As a military general, Jackson was not above interpreting his orders loosely and certainly did not think he had to wait on congressional approval before taking offensive military action. In the wake of the War of 1812 , Jackson concluded that

6. See Remini, supra note 5 , at 35 . 
the Spanish had to be expelled from the Southwest in order for American expansion to occur without hindrance. 7 The first step in his strategy was to eliminate any possibility of an Indian buffer zone between the United States and Spain. After some initial setbacks, Jackson defeated several Creek Indian tribes that had allied with the British during the War-it was in these battles that Jackson won the nickname "Old Hickory." During the peace, Jackson refused to follow the provisions of the Treaty of Ghent that did not recognize his victories. Instead he made several agreements and treaties with the tribes to remove them from the area of the Louisiana Purchase to lands on the western frontier. In about sixteen months Jackson acquired about onethird of Tennessee, three-fourths of Florida and Alabama, onefifth of Georgia and Mississippi, and about one-tenth of Kentucky and North Carolina. Jackson made no secret of his desire to drive the Spanish out of Florida, Texas; and even Mexico. ${ }^{8}$

The Treaty of Ghent and several U.S.-British treaties after the war formalized an implicit understanding between the mother country and her former colony. Great Britain would no longer oppose American expansion into the South and West. In return, the United States demilitarized the northern frontier and gave up any ambitions toward Canada, which had held American attentions since the days of the Revolution. This left Spain in an untenable position in Florida, where it had few military and administrative resources. Americans had wanted Florida since the days of Jefferson, if not before. Congress, however, never authorized any military action against the Spanish. Under prevailing practice at the time, a full offensive mission of conquest would have called for a declaration of war.

Seminole Indian attacks on American territory in 1817 supplied Jackson with a pretext. The Seminoles had operated out of Spanish Florida and also had refused to vacate lands under previous treaties. They undertook retaliatory attacks when American troops sought to relocate them. American

7. 1 REMINI, JACKSON, supra note 1 , at 305 .

8. Id. at 305-07. 
settlers conveniently launched a separate raid into Florida, "liberated" Amelia Island, and then sought the government's help when Spanish forces moved to evict them. The Monroe Administration authorized local commanders to pursue the Seminole raiders across the Florida line, but to stop short and await further orders should the raiders seek shelter in a Spanish outpost. Monroe then placed Jackson in command of a broader expedition and ordered him to "[a]dopt the necessary measure to terminate a conflict" that the President claimed to wish to avoid. ${ }^{9}$ Jackson concluded that the best way to end tensions was to seize all of Spain's territory in Florida. He sent a letter to Monroe seeking authorization, which Monroe subsequently claimed he did not read until a year later.10 Nonetheless, Monroe independently sent Jackson a letter giving him command of the expedition against the Seminoles, the intervention at Amelia Island, and unspecified "other services."11 Monroe urged Jackson that "[t]his is not a time for you to think of repose," declared that " $[\mathrm{g}]$ reat interests are at issue," and asked that "every species of danger" be "settled on the most solid foundation."12

Jackson took this to be authorization to invade Florida. He did not question that the President had the authority to send him; in fact, he had promised Monroe that he would conquer the whole territory within sixty days. In the First Seminole War of 1818 , Jackson led a force of 3,000 regulars and volunteers that destroyed the main Indian settlement near present-day Tallahassee, and captured two British citizens-Alexander Arbuthnot and Robert Ambrister-who had been advising the Seminoles. He convened a military commission to try the two as outlaws under his authority as the commander in the field. After a guilty verdict, he sentenced both to death. Jackson then marched his troops to Pensacola, the seat of Spanish rule in Florida, and quickly seized it on the ground that hostile Indians
9. Id. at 347 .
10. Id.
11. Id. at 348-49.
12. Id. at 349 . 
were massed inside. None were found. A small Spanish force surrendered after a short battle nearby, with no casualties on either side, and were allowed to leave for Cuba. In June, Jackson issued a proclamation declaring Florida to have been ceded to the United States, established a provisional government, and appointed occupation officials. 13

Jackson's battlefield successes sparked a political firestorm. Monroe never tried to stop Jackson's campaigns in the spring and summer of 1818. But after the fighting ended, Secretary of War John Calhoun, later Jackson's Vice President, and Treasury Secretary William Crawford argued that Jackson had violated the Constitution and demanded his punishment. That course would have required Monroe to return Florida, which he was not about to do. Secretary of State John Quincy Adams ironically defended Jackson on the ground that the seizure of Pensacola was justified by military necessity.14 Instead, Monroe sent Jackson a letter maintaining that the general had exceeded his orders, but that circumstances justified pursuit of the Indians into Spanish territory-even though under the Constitution the attack on Pensacola required a declaration of war from Congress. 15 Jackson took full responsibility for the invasion, but continued to claim that Monroe had authorized it. Congress initiated an investigation and Speaker of the House Clay sought Jackson's censure, along with legislation prohibiting the Executive from invading foreign territory without congressional permission. 16 As Jackson journeyed to Washington to personally manage his defense, public opinion turned strongly in his favor. 17 Clay's proposals were resoundingly defeated in the House by $2-1$ margins. 18 Meanwhile, Adams justified Jackson's attacks to the Spanish government as necessary to prevent further Indian

13. Id. at 351-64.

14. Id. at 367 .

15. Id. at $367-68$.

16. Id. at $371-74$.

17. Id. at 373 .

18. Id. at 374 . 
attacks on Americans.19 On February 22, 1819, Adams reached an agreement with the Spanish in the Adams-Onis Treaty ceding Florida to the United States in exchange for American assumption of claims against Spain of up to $\$ 5$ million. 20

As President, Jackson had no occasion to lead the nation into war. Yet he never lost his belief that the Spanish, and their Mexican successors, should give ground to the Americans. Jackson pursued the acquisition of Texas throughout his Presidency. Jackson believed that the United States had acquired Texas in the Louisiana Purchase, and blamed the Adams-Onis treaty for giving up Texas and for the "dismemberment" of the American empire.21 Upon assuming the Presidency, he sent envoys to Mexico City to negotiate for Texas; they made matters worse by writing to the President about the Mexicans' susceptibility to bribery and corruption in letters that found their way into the press.22 Meanwhile, Americans within Texas agitated for independence and annexation. About 35,000 Americans, some with slaves, had settled in Texas at the open invitation of the Mexican government between 1821 (the year of independence from Spain) and 1835. When Jackson's efforts to buy Texas failed, Americans in Texas took matters into their own hands.

In November 1835, Texans established a provisional government, and in the spring of 1836, declared independence. General Santa Anna, who had established a military government over Mexico, sought to put down the rebellion with 6,000 troops. After he reduced the Alamo and executed the survivors, Santa Anna met defeat at the hands of Sam Houston, the former Governor of Tennessee and Jackson's close friend, on April 21, 1836 at the Battle of San Jacinto. Captured, Santa Anna ordered Mexican troops out of Texas and signed treaties recognizing the withdrawal. Although news of the victory thrilled the American

19. See id. at 369 .

20. Id.

21. 3 REMINI, JACKSON, supra note 1 , at 352 .

22. Id. at 354-55. 
public, it also re-opened the question of slavery in the territories. Texas sent delegations seeking annexation, but abolitionists and Northern leaders worried that its addition would give the slave states an advantage in the Senate. 23 Jackson was unwilling to move forward with annexation because he worried that sectional divisions over slavery would complicate the election of his chosen successor, Martin Van Buren; nor did he want to move world opinion against the United States. ${ }^{24}$ He left the matter to Congress to decide, as under the Constitution it controlled the acquisition of new territory and the admission of states. After both the House and Senate appropriated funds and confirmed an envoy to Texas, Jackson decided (on the day before his last in office) to recognize Texan independence. Recognition paved the way for the incorporation of Texas in 1845.25 The Constitution nowhere granted the Executive the explicit power to recognize foreign nations, but Presidents and Congresses had long considered it part of the executive power over foreign relations. Jackson was no different.

A second pillar of Jackson's support for western expansion was his support for the policy of Indian removal.26 In order to fulfill the promise of the West, settlers needed land. Millions of acres in the Southwest, however, remained in the hands of Indian tribes under federal treaties; the Cherokee tribe, for example, possessed more than six million acres in Georgia. The Cherokee had their own constitution and laws. Georgia launched an effort to force them to leave by imposing state law, and to

23. Id. at $359-60$.

24. $I d$.

25. The admission of Texas itself would mark an expansion of executive power. Initially, under President John Tyler, the Senate rejected a treaty annexing Texas by a vote of 35 to 16 on June 8, 1844. After James Polk defeated Henry Clay in the presidential election that November, Congress enacted a simple statute approving the annexation and admitting Texas as a state by a vote of 120 to 98 in the House and 27 to 25 in the Senate. President Tyler signed the law on March 1, 1845, just before Polk was inaugurated. See Vasan Kesavan \& Michael Stokes Paulsen, Let's Mess With Texas, 82 Tex. L. REV. 1587, 1592-93 (2004).

26. See HowE, supra note 1 , at $342-57$. 
keep white Americans from assisting them.27 Federal policy recognized the Indian tribes were self-governing sovereigns, they should remain on their lands, and missionaries should be sent to civilize them. 28 Jackson held a very different view. He saw removal of the Indians as advancing America's economic development and enhancing its strategic position in the Southwest. Removing the Indians would open up fertile lands in the West to white settlement, and it would eliminate an anomaly from America's sovereignty. ${ }^{29}$ Jackson also believed that whites and Indians could not live together and that the best solution was to keep the races apart 30

In his first State of the Union Address, Jackson announced his support for Georgia. To allow the Cherokee to administer their own laws, he declared, would create an independent state within the borders of Georgia.31. He told Congress that he had "informed the Indians that their attempt to establish an independent government would not be countenanced by the Executive of the United States." 32 Jackson said he "advised them to emigrate beyond the Mississippi or submit" to state law. ${ }^{33}$ Jackson knew that the Indians would be unable to live under state law and that they would have little option but to emigrate. ${ }^{34}$

Jackson's interpretation of the Constitution represented a 180 degree change in federal policy. Unlike Presidents today, Jackson showed little hesitation in announcing an independent opinion on the Constitution's meaning. He did not look to

27. Id. at 346 .

28. MAGLIOCCA, supra note 1 , at 14-15.

29. HowE, supra note 1 , at 347 .

30. MAGLIOCCA, supra note 1, at 14-15, 22-29.

31. Jackson, First Annual Message to Congress, supra note 2, at 457-58. Article IV, Section 3 of the United States Constitution states that "New states may be admitted by the Congress into this Union; but no new State shall be formed or erected within the Jurisdiction of any other State ... without the consent of the legislatures of the States concerned as well as of the Congress."

32. Jackson, First Annual Message to Congress, supra note 2, at 458.

33. $I d$.

34. See HowE, supra note 1 , at 348 . 
judicial decisions for guidance. The Marshall Court would not clearly identify the constitutional status of the Indian tribes until 1831.35 On the merits, Jackson's interpretation seems mistaken. When the federal government granted the Indian tribes the right to enforce their own laws, it did not make them states. Indian tribes did not receive two votes in the Senate, for example, nor did they receive any House Representatives or votes in the Electoral College, as required by the Constitution. Nothing in the Constitution prohibited the exercise of sovereignty by a tribe within a state.

Jackson placed the Indian Removal Bill at the top of the legislative agenda for his first year in office. 36 It set aside land west of the Mississippi for the Cherokee, should they voluntarily choose to leave their lands in Georgia. To force them to move, it rejected Cherokee claims to sovereignty and subjected them to state laws. The Removal Bill was consistent with Jackson's general view of allowing the states to regulate all matters not specifically given to the federal government. Critics, led by Northern Christian groups, accused Georgia of violating federal treaties and attacked the Administration for racism. Fierce public opposition to the bill mobilized a permanent anti-Jackson movement throughout the country and led to a split between free and slave states. It passed handily in the Senate, but by only 102-97 in the House in 1830.37

Indians and their allies challenged Jackson in the courts. The Supreme Court threw out their first attempt to prevent Georgia from enforcing its laws because they were not a "foreign nation" that could appear in federal court. 38 Georgia had already declared that it would not obey the Supreme Court, and Jackson's supporters in Congress introduced a bill to repeal Section 25 of the Judiciary Act of 1789, which had given the

35. Cherokee Nation v. Georgia, 30 U.S. 1 (1831).

36. Howe, supra note 1 , at 347 .

37. Howe, supra note 1, at 352; Act of May 28, 1830, ch. 148, 4 Stat. 411, $21^{\text {st }}$ Cong. ( $1^{\text {st }}$ Sess. 1830).

38. Cherokee Nation, 30 U.S. 1 (1831). 
Court jurisdiction over state court judgments. ${ }^{39}$ The Cherokee did win a partial victory, however, because the Court declared that Indians were not simply citizens of Georgia, but instead were "domestic dependent nations" in a "state of pupilage," in which "their relations to the United States resemble that of a ward to his guardian." 40 The right case came along immediately when Georgia sought to eject Christian missionaries living among the Cherokee, and arrested and jailed those who refused to obey. Two missionaries, Samuel Worcester and Elizur Butler, challenged their imprisonment to the Supreme Court. In Worcester v. Georgia, Chief Justice Marshall struck down the Cherokee Codes, not because they violated treaties with the Indians, but because they violated the Constitution. ${ }^{41}$ According to Marshall, the "Indian nations had always been considered as distinct, independent political communities, retaining their original natural rights, as the undisputed possessors of the soil, from time immemorial." 42 The Constitution, the Court held, gave complete control over all relations with the Indians to the federal government and ousted the states from the same.

Georgia refused to appear before the Court and made no moves to obey the Court's ruling. The crisis prompted Jackson to display his vision of an independent Executive. Jackson took no action to enforce the Supreme Court's judgment. "Well, John Marshall has made his decision, now let him enforce it," Jackson was reported to have said.43 Historians have disputed whether Jackson actually uttered those words, which were reported second-hand in a book long after he left office. According to Daniel Howe's recent work, however, the comments were "consistent with Jackson's behavior and quite in character." 44

39. MAGLIOCCA, supra note 1 , at 36.

40. Cherokee Nation, 30 U.S. at 17.

41. Worcester v. Georgia, 31 U.S. 515, 561 (1.832).

42. Id. at 559. For an insightful discussion of Worcester, see Philip P. Frickey, Marshalling Past and Present: Colonialism, Constitutionalism, and Interpretation in Federal Indian Law, 107 HARV. L. REV. 381 (1993).

43. COLE, supra note 1, at 114.

44. Howe, supra note 1 , at 412 n.2. 
They illustrate Jackson's pugnacity, his Indian policy, and his view of the President's position in the constitutional system. Jackson followed Jefferson's belief that the executive had an equal right to interpret and enforce his own vision of the Constitution-a path he would pursue to great effect in his battle with the Bank of the United States. As he had made clear in his State of the Union Address, Jackson believed that the federal government did not enjoy the sole prerogative to regulate the Indian tribes. Nor did he feel a constitutional obligation to obey the interpretation of the Constitution held by another branch.

Although Jackson did nothing to support the Court's constitutional powers, he acted to defuse the political crisis. Rather than defy the Supreme Court outright, the Georgia courts simply refused to acknowledge the Supreme Court's decision. Without any formal acceptance or rejection of Worcester by the state courts, the Supreme Court had no formal legal authority to order Georgia to obey the decision. 45 Even if Georgia had openly refused to obey Worcester, the Supreme Court recessed for nine months and was unable to reverse the State's decisions.46 Jackson commented that "the decision of the supreme court has fell still born, and they find they cannot coerce Georgia to yield to its mandate." 47 The confrontation, however, generated political trouble for the Administration. Newspapers widely reprinted Worcester, which served as ammunition to attack Jackson in his soon-approaching re-election campaign. Jackson and Van Buren worked through the party machinery to convince the Governor of Georgia to commute the sentences in exchange for the missionaries' agreement not to seek further Court review.48 Indian issues would figure in the election of 1832 , and Jackson would take his overwhelming re-election as a validation of his Indian removal policy.

In Jackson's second term, the United States moved swiftly to

45. $I d$.

46. $I d$.

47. Id.

48. Id. at $412-13$. 
remove the Indians from the western states. In 1835 , a rump Cherokee government agreed to a treaty that traded their Georgia lands for five million dollars and land in Oklahoma.49 The Senate ratified the agreement by only one vote. In 1838 , 12,000 Cherokee migrated to the West on the "Trail of Tears;" it is estimated that 4,000 died.50 The U.S. Army forced the Cherokee to leave without any preparations for the long journey and a hard winter. By our standards today, American treatment of the Indians is shocking and repulsive.51 Under the standards of his time, Jackson's views can be said to represent the views of the voting public.

Jackson may have honestly believed that the lot of the Indians would be improved by distance from whites. His actions may have even prevented their wholesale destruction, which could have occurred had they attempted to remain in Georgia and other western states. He achieved what he had wanted - the removal of a perceived obstacle to the growth of the American republic. Jackson opened up 100 million acres to white settlers in exchange for 30 million acres in Oklahoma and Kansas and seventy million dollars.52 Although he believed himself to be protecting the Indians by keeping them apart from whites, he also wanted to open the best farmland to white settlers and to impose state law so as to drive the Indians out. His policy produced Indian removal at a significant cost in lives. While the Trail of Tears occurred after Jackson left office, he surely bears great responsibility for the tragedy, and he used the power of the Presidency to bring it about.

\section{THE BANK WAR}

Jackson's broad vision of his executive powers in foreign

49. Id. at 415 .

50. $I d$. at 416 .

51. For the claim that Jackson's removal policy amounted to genocide, see Michael P. Rogin, Fathers and Children: ANDREW JaCkson and the SUBJUGATION OF THE AMERICAN INDIAN (1975).

52. HowE, supra note 1 , at 420 . 
affairs was exceeded by the exercise of his constitutional powers domestically. He placed the constitutional powers of the officeremoval, the veto, and the power to execute and interpret the law-in the service of a new constitutional theory of the office. For Jackson, the Presidency did not just rest on the same plateau with the other branches of government. It was the primus inter pares-the first among equals. Jackson conceptualized the Presidency as the direct representative of the American people, the only official in the federal government elected by the majority. He proceeded to exercise a broad interpretation of his constitutional powers, sometimes in conflict with Congress and the courts, because he believed he was promoting the wishes of the American people. Jackson's attachment to the people came through in the symbolic-as in his First Inaugural, when he opened the White House to any and all, who then proceeded to storm through the building destroying furniture, carpets, and fine china ${ }^{53}$ - and the real, as when he took his re-election as a mandate to destroy the Bank of the United States.

At first, Jackson resorted to these powers just to keep his administration from imploding. As he entered office, Jackson made the basic mistake of appointing members of his cabinet who turned out to be at odds with one another. This problem was compounded by the presence of Vice President John Calhoun, who, unbeknownst to Jackson, had accused him while in the Monroe administration of waging an illegal war in Florida-and would become one of Jackson's fiercest political opponents. Dissension began, however, not over policy but over a marriage. Tennessee Senator and close friend John Eaton, whom Jackson appointed Secretary of War, had allegedly carried on an affair with Peggy Timberlake, his landlord's daughter.54 Not only was Ms. Timberlake much younger than the Senator, but she was married to a Navy purser who then allegedly killed himself because of her behavior.55 Eaton married Peggy, setting off a

53. Cole, supra note 1 , at 34 .

54. 2 REMINI, JACKSON, supra note 1, at 62, 161.

55. COLE, supra note 1, at 23-24. 
social scandal that rocked the administration. The wives of Administration officials, such as Vice President Calhoun and the Secretaries of the Treasury and Navy, as well as the Attorney General and Jackson's close friends and aides openly snubbed the new Mrs. Eaton at social events. 56 Her supporters included Secretary of State Martin Van Buren, the Postmaster General, and two of Jackson's presidential advisors. ${ }^{57}$

As Donald Cole has observed, the issue dominated Jackson's first years in office, and led to Calhoun's downfall.58 Because of the social division, the members of Jackson's cabinet were barely on speaking terms. The first term ground to a halt. Jackson, who took the insults to heart and personally conducted research in Mrs. Eaton's defense, came to see the whole affair as an effort by Calhoun to succeed him in office.59 By the end of 1829, Jackson switched his favor from Calhoun to Van Buren, who was known as "the Little Magician" for his political and organizational skills in creating an extensive political machine to elect Jackson in New York.60 Jackson found his solution in his power of removal. Although Jefferson had replaced Federalist officials over time, he did not do so on a large scale. Jackson believed in the wholesale replacement of executive branch officials as a matter of policy and party patronage. He believed that his popular election gave him the right, in the name of reform, to replace those "unfaithful or incompetent hands" who held power, as he said in his First Inaugural Address, with officers of "diligence and talent" who would be promoted based on their "integrity and zeal." 61 Jackson believed that the concentration of power in the hands of long-serving public officials threatened American liberty.62 Jackson praised

56. Id. at $35-36$.

57. $I d$.

58. Id. at 38 .

59. Id. at 37 .

60. 2 REMINI, JACKSON, supra note 1, at 213-14.

61. Andrew Jackson, First Inaugural Address (Mar. 4, 1829), in 2 Messages and Papers of the Presidents, 438 (James D. Richardson ed., 1896).

62. 2 REMINI, JACKSON, supra note 1, at 183. 
"rotation" in office as "a leading principle of the republican creed."63 For Jackson, "as few impediments as possible should exist to the free operation of the public will," and appointments to public office should reflect the results of the presidential election. 64

In his first year in office, Jackson moved quickly to put his words into effect. Of about 11,000 federal officials, Jackson removed somewhere between ten to twenty percent in his first year.65 Of those directly appointed by the President, he removed fully forty-five percent, more than all of his predecessors put together.66 Jackson believed he should have a bureaucracy that would support his program, but historians ever since have blamed him for introducing the "spoils system" into American politics and ruining a relatively honest and efficient federal bureaucracy. 67 Jackson's policy of rotation in office, or of partisan patronage, required a robust view of the President's constitutional authority to hire and fire all those in the executive branch.

Removal became the answer to the Eaton affair. By 1831, the break with Calhoun was complete when Jackson obtained documents showing that Calhoun had attacked him during the invasion of Florida. 68 In a letter to Calhoun accusing him of "endeavoring to destroy" his reputation, Jackson wrote "in the language of Caesar, Et tu Brute," and declared that "[n]o further communication" between the two would be necessary.69 Calhoun published in the newspapers his correspondence with the President on the Seminole Wars, in an effort to show that others-particularly Van Buren-were attempting to destroy his

63. Jackson, First Annual Message to Congress, supra note 2, at 449.

64. Id. at 448-49.

65. COLE, supra note 1 , at 41.

66. Id.; HowE, supra note 1 , at 333 .

67. LEONARD WhiTE, THE JACKSONIANS: A STUDY IN ADMINISTRATIVE HISTORY 327-32 (1954); HOWE, supra note 1, at 334.

68. COLE, supra note 1 , at 80 .

69. Id. at 81 (Jackson to Calhoun, May 30, 1830). 
career. ${ }^{70}$ Jackson and the nation were shocked by the public airing of political dirty laundry. He could not remove the Vice President, but he could fire his quarrelsome cabinet en masseespecially its Calhoun supporters. Jackson became the first President to demand the resignation of his entire cabinet at once. ${ }^{71}$ He made clear that he would use his power of removal vigorously, and that cabinet members had no constitutional right to the autonomy to which they had become accustomed. It struck the nation like a thunderclap; never before had so many resignations of high office occurred at once. But it also served its greater purpose-it allowed Jackson to end the political infighting within his administration and to refocus it on his policy goals. Jackson's control over the executive branch and the party would become even clearer when he decided in 1832 to push Calhoun off the Democratic ticket and to replace him with Van Buren.

The firings would provide the space for Roger Taney-who would play a central part in Jackson's next great constitutional fight- to enter the cabinet as Attorney General. It is difficult today to understand why the Bank of the United States would spark a titanic political fight. Who would oppose the Federal Reserve Bank today after its success in beating inflation and keeping economic growth steady? Or the idea of keeping control of the money supply out of the hands of politicians? Yet, Jackson made a point of mentioning the Bank at the end of his First Annual Message to Congress. He observed that "[b]oth the constitutionality and the expediency of the law creating this bank are well questioned by a large portion of our fellow-citizens," and he declared that "it has failed in the great end of establishing a uniform and sound currency."72 Jackson recommended that if Congress were to keep the bank, significant changes in its charter were necessary. 73

70. Id. at 82 .

71. Id. at $84-85$.

72. Jackson, First Annual Message to Congress, supra note 2, at 462.

73. Id. 
Jackson's hostility toward the Bank was shared by many Americans of the time. It makes sense only because the Bank of the United States was a wholly different creature from the Federal Reserve of today. The legislation establishing the first Bank of the United States, the one signed by George Washington and over which Hamilton and Jefferson fought, expired just before the War of 1812.74 Part of the nation's terrible record in that war was due to the government's difficulties in financing the military without a national bank.75 Lesson learned, Congress established the Second Bank of the United States in 1816.76 Madison, who had argued against the constitutionality of the first Bank while in Congress during the Washington administration, signed the legislation as President. In a veto of an earlier version of the bill, he had "[w]aiv[ed] the question of the constitutional authority of the Legislature" because of "repeated recognitions under varied circumstances of the validity of such an institution in acts of the legislative, executive, and judicial branches." 77 Madison further conceded that the Bank's legality had been established by additional "indications, in difference modes, of a concurrence of the general will of the nation."78 In the famous case of McCulloch v. Maryland, studied to this day by every law student, Chief Justice Marshall upheld the constitutionality of the Bank in 1819 along lines similar to those of Alexander Hamilton's: although unmentioned in the constitutional text, a national bank fell within Congress's Necessary and Proper Clause power because it allowed the government to effectively exercise its tax, spending, commerce, and war powers. 79

As he suggested in his First Annual Message, Jackson did not feel bound to Madison's view or that of the Supreme Court.

74. CoLE, supra note 1 , at 57 .

75. Id.

76. $I d$.

77. James Madison, Veto Message (Jan. 30, 1815), in 1 Messages AND PAPERS OF THE PRESIDENTS 555 (James D. Richardson ed., 1896).

78. $I d$.

79. McCulloch v. Maryland, 17 U.S. 316 (1819). 
Jackson's objections to the Bank were not just constitutional. He believed that the concentration of power in the Bank threatened American liberties. By the time Jackson became President, the Second Bank had come to dominate the American economy and finance in a way unmatched by any other company or institution since. It was a private corporation chartered by the federal government, which held one-fifth of its stock and appointed onefifth of the directors. By law, only the Second Bank could keep and transfer government funds, help in the collection of taxes, loan money to the government, and issue federal bank notes. Its $\$ 13$ million in notes, which served as a form of paper currency, made up almost forty percent of all notes in circulation, and its $\$ 35$ million in capital was more than double the annual federal budget. 80 It made twenty percent of all loans and held more than one-quarter of all bank deposits in the nation.81 States could also charter banks which issued notes, but those notes often came into the possession of the Second Bank during the course of normal business. 82 Because it could call in those notes for repayment at any time, the Second Bank effectively dictated the credit reserves of the state banks, and thus of the entire national banking system. 83 As with the Federal Reserve Bank today, the Second Bank's control over the supply of money allowed it to influence, if not control, the nation's lending activities, interest rates, and economic growth. Its stock was held by 4,000 shareholders, 500 of them foreigners, who enjoyed profits of eight to ten percent per year. 84

Jackson decided to rein in, and then destroy, the Second Bank. He viewed it as an institution that benefited a small financial elite. Corruption and outright embezzlement plagued its earlier years. The first president of the bank, a former navy and treasury secretary appointed by Madison, speculated in the

80. COLE, supra note 1 , at 57.

81. Id.

82. Id.

83. Id.

84. See id.; WILENTZ, supra note 1 , at 76 ; see generally WALTER SMITH, ECONOMIC ASPECTS OF THE SECOND BANK OF THE UNITED STATES (1969). 
Bank's stock, benefited from corrupt branch operations, and almost drove the Bank into bankruptcy. ${ }^{85}$ He resigned after a congressional investigation.86 Under the next president, the Bank was widely blamed for the Panic of 1819 , which caused state banks to close their doors, bankrupted many farmers and businesses, and sparked a sharp increase in unemployment. 87 The years after the War of 1812 witnessed a dramatic increase in land speculation fueled by bank notes. During the Panic, the Second Bank demanded that state banks redeem their notes in hard currency, which caused a sharp contraction of credit, a run of bankruptcies, and a sharp increase in unemployment.88 Jackson was elected to the Senate by the Tennessee legislature in 1823 in part because of his public stance against the Bank during the Panic. Political movements rose to oppose the Bank, with states enacting laws heavily taxing the Bank or trying to drive branches out of their territory. 89 After the Panic, Jackson remained hostile to the Second Bank because he believed it concentrated economic and political power in the few hands that dictated legislation, handed out patronage, guided elections, and influenced government operations.

Ironically, by the time Jackson became President, the Bank had changed its ways and had become a powerful aid to the striking economic expansion of the 1820 s and 1830s. Under President Nicholas Biddle, the scion of a patrician Philadelphia family, the Second Bank cleaned up its finances.90 It ended internal corruption and kept a reserve of hard currency worth roughly half the amount of notes outstanding to prevent the speculative practices that produced the Panic. Through its special relationship with the federal government and its holdings

85. Robert V. REMini, ANDREW Jackson and the Bank WaR: A STUd IN THE GRowTH OF PRESIDENTIAL POWER 27 (1967) [hereinafter REMINI, BANK WAR].

86. Id.

87. Id. at $27-28$.

88. For one economist's account, see MurRay Rothbard, PANIC of 1819: REACTIONS AND POLICIES (1962).

89. REMINI, BANK WAR, supra note 85 , at $30-31$.

90. Id. at $32-33,39$. 
of specie and state bank notes, it effectively controlled the national money supply and had a profound effect, as does the central bank today, on the amount of credit and growth in the economy. 91 Biddle believed that government oversight and public involvement in the Bank's operations were unwelcome and unnecessary. 92 He made sure his influence was felt by paying newspaper editors and legislators to defend the Bank. Daniel Webster, who became a leader of the Jacksonian opposition, served for a time on the board of directors. Biddle was not a corrupt speculator, as were some of his predecessors, but a highly educated, intelligent man of affairs who brought great ability and energy to the job of administration. Neither Biddle nor his Bank would go quietly. 93

The approach of the 1832 presidential elections prompted the first round in the fight between Jackson and Biddle's Bank. In his Second Annual Message to Congress, Jackson proposed folding the Bank into the Treasury Department, but the legislation establishing the Bank itself was not up for reauthorization until 1836.94 As the elections neared, Jackson agreed not to seek any changes in the Bank's charter until after the elections.95 But a convention of National Republicans-the group that split off from the Democratic Party to oppose Jackson-nominated Henry Clay in December, 1831 as their presidential candidate. 96 Sensing a political opportunity to make Jackson's opposition to the Bank his winning campaign issue, Clay convinced Biddle to seek renewal of the Bank's charter four years early. 97 Both the House Ways and Means Committee and the Senate Finance Committee had issued reports the previous

91. Id. at $37-38$.

92. Id. at 34-35.

93. Id.

94. Andrew Jackson, Second Annual Message to Congress (Dec. 6, 1830), in 2 Messages AND PAPERS OF THE PREsidents 529 (James D. Richardson ed., 1896).

95. REMINI, BANK WAR, supra note 85 , at 74 .

96. Id. at 92 .

97. Id. at 75-76. 
year finding the Bank constitutional and praising its operations-Biddle himself had drafted the Senate report. The Bank paid to distribute the reports throughout the country.98 Jackson chose Senator Thomas Hart Benson, with whom he had once fought a duel that ended with a bullet in Jackson's shoulder, to lead the fight against the Bank.99 Clay's supporters in the House and Senate passed the bill in the summer of 1832 by a vote of 28-20 in the Senate and 107-85 in the House.100 To throw salt on Jackson's wounds, the Senate (with Vice President Calhoun casting the tie-breaking vote) even rejected Van Buren's nomination as minister to Great Britain.101 In pushing the Bank Bill and working with Clay, Biddle not only lived up to the charges that the Bank was a politicized institution, but he threw down the gauntlet before a man who had never shrunk from a fight.

The initial setbacks steeled Jackson's determination. Van Buren came to see Jackson at midnight shortly after the votes. Jackson had stretched out on a sofa, his health suffering. Upon greeting his visitor, he declared "The bank, Mr. Van Buren, is trying to kill me, but I will kill it."102 And he did. Jackson issued a thundering veto on July 10, 1832. For the first time in presidential history, a veto message extensively discussed political, social and economic as well as constitutional objections to legislation. 103 Jackson portrayed the bill as a "gratuity" and a "present" transferred from the American people to the Bank's shareholders, including the foreigners who held eight million shares. 104 The Bank constituted a monopoly that benefited "a privileged order, clothed both with great political power and enjoying immense pecuniary advantages from their connection

98. Id. at 99 .

99. Id. at 77-78.

100. Id. at 80 .

101. Id. at 93 .

102. Id. at 15-16 (emphasis added).

103. Andrew Jackson, Veto Message (July 10, 1832), in 2 MESSAGES AND PAPERS OF THE PRESIDENTS 576-91 (James D. Richardson ed., 1896).

104. Id. at 576-77. 
with the Government," at the expense of "merchant, mechanic, or other private citizen[s]" who are not allowed to pay their debts with notes, rather than hard currency. ${ }^{105}$ Such wealth, Jackson argued, ought to give "cause to tremble for the purity of our elections in peace and for the independence of our country in war," because they would use their wealth to "influence elections or control the affairs of the nation."106 Foreign shareholders, Jackson feared, might cause the financial system to collapse during a war--"[c]ontrolling our currency, receiving our public moneys, and holding thousands of our citizens in dependence" would pose a greater threat to national security than an enemy's armies and navies. 107

Although it broke from practice by introducing his policy views, the lasting impact of Jackson's veto message remains his thinking on the President's independent authority to interpret and enforce the Constitution. He conceded that the precedents of the Supreme Court and previous Congresses had upheld the bank.108 Jackson, however, declared that the Constitution established the Executive as an independent and coordinate branch whose decisions could not be dictated by the Court. "The Congress, the Executive, and the Court must each for itself be guided by its own opinion of the Constitution," Jackson wrote. 109 In fulfilling its constitutional functions, each branch has an equal and independent duty to decide upon the constitutionality of legislation, whether in passing it, enforcing it, or adjudicating it. "The opinion of the judges has no more authority over Congress than the opinion of Congress has over the judges," Jackson declared.110 And, he emphasized, "on that point the President is independent of both." 111 He concluded that "[t]he authority of the Supreme Court must not, therefore, be permitted to control the

105. Id. at 578 .

106. Id. at 581 .

107. Id.

108. Id. at 582 .

109. Id.

110. $I d$.

111. Id. 
Congress or the Executive when acting in their legislative capacities . . ." 112 Jackson would only grant the courts "such influence as the force of their reasoning may deserve."113

Jackson remained convinced that Jefferson had been right in 1791. A national bank was not necessary and proper to carry into execution the government's constitutional powers, because it was not truly indispensable. Congress, for example, has the power to coin money. It had already established a mint; therefore, a national bank could not truly be necessary and proper to execute Congress's power. Jackson closed by linking his constitutional and policy objections to the higher goal of democracy and liberty:

It is to be regretted that the rich and powerful too often bend the acts of government to their selfish purposes. Distinctions in society will always exist under every just government. Equality of talents, of education, or of wealth can not be produced by human institutions. In the full enjoyment of the gifts of Heaven and the fruits of superior industry, economy, and virtue, every man is equally entitled to protection by law; but when the laws undertake to add to these natural and just advantages artificial distinctions, to grant titles, gratuities, and exclusive privileges, to make the rich richer and the potent more powerful, the humble members of society-the farmers, mechanics, and laborers-who have neither the time nor the means of securing like favors to themselves, have a right to complain of the injustice of their Government. There are no necessary evils in government. Its evils exist only in its abuses. If it would confine itself to equal protection, and, as Heaven does its rains, shower its favors alike on the high and the low, the rich and the poor, it would be an unqualified blessing. In the act before me there seems to be a wide and unnecessary departure from these just principles. 114

Jackson's call to freedom does not fit modern conceptions of

112. Id.

113. Id.

114. Id. at 590. 
either liberal or conservative policy, but seems more libertarian. He wanted to support the common man, but by reducing rather than expanding the role of government in society. Deregulation, however, would not benefit big business. Instead, Jackson believed that government regulation entrenched the rich in power; getting the government out of the way would allow individual talents and merit to come to the fore.

Before Jackson, Presidents had vetoed nine pieces of legislation; Jackson vetoed twelve. $\mathrm{He}$ was also the first President to make use of the "pocket veto," in which the Constitution allows the executive to veto bills enacted just before Congress goes into recess without the possibility of override. Washington set the precedent for the use of the veto purely on policy grounds, but it was Jackson who transformed the power into one that gave the President significant leverage in the legislative process itself. The President would not just protect the Constitution against encroachment by the legislature, although that would continue to be one function of the veto. Jackson made the President a permanent player in the legislative process, one whose power far exceeded any individual member of Congress. As Leonard White has observed, Jackson endowed the Presidency with the political force of two-thirds of Congress. 115 Because of Jackson, any modern President with the support of thirty-four senators can completely stall any proposed legislation. Not only does the veto give the President tremendous blocking power, but the mere threat of a veto provides him with significant political advantage in influencing legislation.116 Forceful Presidents have combined the veto power with the right to propose bills to ensure that Congress begins with the administration's proposed legislation first.

Jackson also made sure that Congress would worry about the President's views on the Constitution. Jackson's veto of the Bank

115. Leonard D. White, The Jacksonians: A STUdy in Administrative HISTORY: 1829-1861 29 (1954).

116. See generally Charles M. Cameron, Veto Bargaining: Presidents and THE POLITICS OF NEGATIVE POWER (2000). 
presented a striking declaration of independence from the other branches of government. He gave no deference to the views of Congress, the Supreme Court, or even past Presidents on the constitutionality of the Bank. Jackson believed that as President, he had a duty to decide for himself what the Constitution meant and to use the powers of the Presidency to advance that vision. Jackson's was not a passive vision of the Presidency, nor was it limited to self-defense of the office. He did not limit his powers solely to protecting the Presidency from the encroachments of the other branches. As with the Bank, Jackson believed that the President should use his power affirmatively to prevent the other branches from violating his view of the Constitution, even if their policy did not infringe on executive branch prerogatives. Of course, Jackson's Bank message implies that the other branches were also free to use their authority to advance their constitutional views, and that they were in no way bound by the President.

Jackson's veto was met with howls of protest. Biddle wrote to Clay that Jackson was a demagogue calling for anarchy.117 Webster gave a speech in the Senate portraying the President as grabbing for "despotic power."118 "[A]lthough Congress may have passed a law, and although the Supreme Court may have pronounced it constitutional," Webster said, "yet it is, nevertheless, no law at all, if he, in his good pleasure, sees fit to deny it effect; in other words, to repeal and annul it."119 Webster foresaw that Jackson's example would lead to the presidential influence over legislation we see today. His veto message "claims for the President, not the power of approval, but the primary power, the power of originating laws." 120 Following with a harsh attack, Clay argued that the veto was to be used in extraordinary moments when Congress had acted rashly.121 Now, Clay

117. REMINI, BANK WAR, supra note 85 , at 84 .

118. Id. at $84-85$.

119. Id. at 84 .

120. Id. at 85 .

121. Id. 
observed, the President's veto had become a threat used to influence legislation, which was "hardly reconcilable with the genius of representative government." 122 Every time Presidents expand the power of the Executive branch, members of Congress invariably respond with claims that tyranny is coming or the end of democratic government is on its way.

Jackson's July, 1832 veto bolstered his claims that the Presidency served as the direct representative of the American people. He obviously aimed his message not to Congress, but to the American people. It was reproduced in newspapers and pamphlets by the tens of thousands, some at the expense of Biddle, who thought the arguments so specious that they made for good propaganda. More importantly, with the presidential elections approaching, Jackson was asking the people to decide the Bank issue by voting for him. As Remini writes, "[n]ever before had a chief executive taken a strong stand on an important issue, couched his position in provocative language, and challenged the American people to do something about it if they did not approve."123 Jackson transformed the presidential election into a plebiscite-the 1832 presidential election gave the voters a choice between Jackson or the Second Bank. Victory in the 1832 election would give the President a popular mandate to pursue the destruction of the Bank. Jefferson, too, had turned the election of 1800 into a referendum, but it was not so much on a single issue as it was a struggle between the Federalists and Republicans for power. Jackson's reelection campaign turned on a single issue, which would give him great political support for his policy if he won.

The first nominating conventions, held by the two parties in 1832 , strengthened the link between popular wishes and his reelection. There was no mistake about the issues involvedJackson's exercise of his constitutional powers stayed at the center of the election. National Republicans, who nominated Clay and counted Webster and Calhoun among their leaders,

122. Id.

123. Id. at 87. 
argued that Jackson had seized unconstitutional powers and was bent on political spoils and tyranny. ${ }^{124}$ A National Republican newspaper, for example, accused Jackson of annulling "two houses of Congress, the Supreme Court, and the Constitution of the United States."125 Another asked, regarding Jackson and his veto, "[c]ould it have any effect but to swell the power and augment the influence of the Executive . . .?"126 A third declared that the Constitution was "a dead letter, and the will of a DICTATOR is the Supreme Law!"127

Democrats responded that Jackson represented democracy and the wishes of the common man against the concentrated power of the Bank and a wealthy aristocracy.128 They had the luck to fight against a Bank determined to make itself a bigger target by interfering in the election. Biddle paid for the reprinting of Webster's and Clay's speeches against the veto, and poured roughly $\$ 100,000$ into the campaign to defeat the General.129 Democrats used this as ammunition against Clay, claiming he fronted for a Bank that was trying to buy the election and bribe public officials.130 Rather than run from Jackson's use of presidential power, Democrats welcomed the focus on their leader and used mass rallies, parades, and campaign events to make him the center of the campaign. 131

Jackson won re-election overwhelmingly. He won 219 electoral votes to Clay's forty-nine, with a third party candidate receiving seven.132 Jackson won all of the South and the West except for Clay's home state of Kentucky and South Carolina, which gave its votes to someone who was not running (for reasons which will become clear). He lost only four other states,

\footnotetext{
124. Id. at 90-101.

125. Id. at 101.

126. Id.

127. Id.

128. Id. at 99-100.

129. Id. at $98-99$.

130. Id. at 99 .

131. Id. at 103-04.

132. Id. at 105.
} 
all in the Northeast. He won about fifty-five percent of the popular vote, with 687,502 in his favor against 530,189 for his opponents, a slight decline from his percentage of the vote in the first election. ${ }^{133}$ The election vindicated Jackson's decision to gamble the election over his opposition to the Bank and his exercise of presidential power. It transformed the nature of the office by grounding his political support on the majority, rather than the states, the Electoral College, or his political party. Jackson would use this broad base to claim that his views on policy were those of the American people, and to lay an equal, if not superior, claim to that of Congress for the mantle of representative of the democracy.

Jackson began his second term with a renewed offensive against the Bank. It was not enough for the General to wait for "the Monster" to disappear in four years. In Spring 1833, Jackson decided to withdraw all federal funds from the Bank and transfer them to state banks.134 Withdrawal would drain about half of the deposits from the Bank, effectively crippling it. Jackson believed that this would prevent Biddle from pushing a re-charter bill through Congress. ${ }^{135}$ It also placed the General in his favorite position, that of dictating events. On March 19, Jackson read a paper to his Cabinet laying out his policy toward the Bank.136 He would not suffer its re-charter and wanted to try managing federal funds through state banks or possibly a new federal bank limited to doing business only in Washington, D.C. (which would not run afoul of Jackson's constitutional objections).137 Only Taney supported Jackson; the rest of the Cabinet thought it best to keep the government's business with the Bank.138 Treasury Secretary Louis McLane argued in a lengthy letter to Jackson against withdrawal of federal funds because of the effect on the economy and worries about

133. Id. at 106.

134. Id. at 109.

135. Id. at 111 .

136. Id. at $112-13$.

137. Id.

138. Id. at 113. 
mismanagement by the state banks. ${ }^{139}$ The 1816 statute establishing the Second Bank authorized only the Treasury Secretary to withdraw federal funds from the Bank and required him to explain his reasons to Congress. ${ }^{140}$ It was also clear that Congress would oppose any withdrawal. The 1832 elections had not given the Jacksonians a majority in the Senate, which remained dominated by Calhoun, Clay, and Webster. Even the Democratic House overwhelmingly declared that federal deposits were safe in the Bank. ${ }^{141}$

The President responded by drawing on his full constitutional powers to get the Bank out of the business of holding the government's money. He sparked a political and constitutional controversy of a kind rarely repeated in the nation's history. Jackson first rearranged his Cabinet to get McLane out of the Treasury-he was moved to Secretary of State- replacing him with William Duane, a known opponent of the Bank.142 Duane, however, got cold feet and sought delay of any decision.143 Jackson took the extraordinary steps of convening a cabinet meeting on September 17, 1833, to notify them of his decision to withdraw the funds, and the next day had Taney read the Cabinet a lengthy "exposé" of the Bank in his name.144 Jackson blamed the Bank for making the re-charter an issue in the presidential election, and for trying to use its financial influence to defeat him. He charged that it was controlling many major newspapers, had delayed the government's efforts to retire the national debt, and had even unjustly charged the government high fees. Jackson interpreted "his reelection as a decision of the people against the bank," and declared that "the people have sustained the President, notwithstanding the array of influence and power which was

139. Id. at 113-14.

140. Act of Apr. 10, 1816, $\S 16,3$ Stat. 266, 274, 14th Cong. (1 ${ }^{\text {st }}$ Sess. 1816).

141. REMINI, BANK WAR, supra note 85, at 111.

142. Id. at 115 .

143. Id. at 116.

144. Id. at 118 . 
brought to bear upon him."145 Jackson portrayed the issue as whether the President or the Bank would govern, which he called "an irresponsible power which has attempted to control the Government."146

Duane still resisted and asked for a delay. Jackson had the government announce the withdrawal of the funds on September $20^{\text {th }}$ anyway. 147 Duane refused to carry out the order. Jackson informed him that as a member of the executive branch, Duane worked for him. "A secretary, sir, . . . is merely an executive agent, a subordinate, and you may say so in self-defense," the President told Duane. 148 Duane claimed, however, that Congress had given him, not the President, the discretion to decide where to deposit federal funds and asked for another delay. "Not a day," Jackson exclaimed, "not an hour."149 Jackson fired Duane in a letter on September $23^{\text {rd }}$ and replaced him with Taney. "I surely caught a tarter in disguise," Jackson explained to Van Buren, "but I have got rid of him."150 Taney began carrying out the withdrawal almost immediately. In this swift action, Jackson gave form to the ideas of Washington and Jefferson. As Chief Executive, Jackson believed it was his constitutional right to decide how to carry out federal law, such as the statute on the deposit of federal funds. In order to execute the law, he had to control subordinate officials in the executive branch. If they would not follow his constitutional views and policy priorities, he would exercise his constitutional authority of removal and replace officials who refused to follow his orders.

Biddle responded with everything he had. His bank began a rapid restriction on credit and called in loans to state banks. 151 State banks responded by calling in their own loans, producing a

145. Andrew Jackson, Removal of the Public Deposits (Sept. 18, 1833), in 3 Messages AND Papers of The PResidents 7 (James D. Richardson ed., 1896).

146. $I d$.

147. REMINI, BANK WAR, supra note 85 , at 122 .

148. Id. at 123.

149. Id. at 124 .

150. Id.

151. Id. at 126-27. 
contraction of lending throughout the national economy.152 The restriction on credit sparked a financial panic, which Biddle hoped would pressure the politicians to re-charter the bank and override Jackson.153 Opposition took political form too. Critics of Jackson coalesced in the winter of 1833 into a new political party, the Whig Party, which took as its main platform (as suggested by its name) opposition to Jackson's expansion of executive power. 154 As head of the new party, Clay convinced the Senate to launch an investigation into the withdrawal of the deposits, and issued a demand for an official copy of the September $18^{\text {th }}$ exposé widely reprinted in the papers. 155

Having used his powers to veto, to fire officials, and to interpret and enforce the law, Jackson next turned to executive privilege. Jackson responded to the Senate with a resounding "no." In a message to the Senate on December 12, 1833, Jackson wrote that "[t]he executive is a coordinate and independent branch of the Government equally with the Senate." 156 He stated that he had "yet to learn under what constitutional authority" the Senate could "require of me an account of any communication, either verbally or in writing, made to the heads of Departments acting as a Cabinet council."157 If he were required to produce the document, Jackson argued, he might as well "be required to detail to the Senate the free and private conversations I have held with those officers on any subject relating to their duties and my own." 158 He saw no reason why the document was needed for the performance of any legislative duty, and he believed production would interfere with the proper

152. Id. at 127.

153. Id. at $126-27$.

154. Id. at 129 ("National Republicans, Bank men, nullifiers, tarriff men, states' righters, former Democrats and other dissidents joined together to form the 'Whig' party, adopting this name to designate their opposition to concentrated power in the hands of the chief executive.").

155. REMINI, BANK WAR, supra note 85, at 137-38.

156. Andrew Jackson, Message to Senate (Dec. 12, 1833), in 3 Messages ANd PAPERs of The PRESidents 36 (James D. Richardson ed., 1896).

157. Id.

158. Id. 
operation of his own branch. Although Jackson did not use the words "executive privilege," his explanation followed the same constitutional basis set out by Washington's message on the Jay Treaty and Jefferson's refusal to obey the Burr subpoena.

Clay responded with an idea that would make an encore appearance during the affairs of Bill Clinton-censuring the President. Although the Jacksonians held a majority of the House, taking impeachment out of the equation, the Whigs still had sufficient support in the Senate. Clay chose to make Jackson's usurpation of constitutional authority the grounds for censure. In his speech on the resolution, Clay exclaimed that "[w]e are ... in the midst of a revolution," because of the veto and the removal of the funds, which was "tending towards a total change of the pure republican character of the Government, and the concentration of all power in the hands of one man." 159 Criticism of Presidents and their exercises of executive power have changed little since the tone set by Clay. The Great Compromiser repudiated Jackson's claim that the President represented the wishes of the democracy. "I am surprised and alarmed at the new source of executive power which is found in the result of a presidential election." 160 According to Clay, the President's sole authority came from the Constitution and the laws, not "loose opinions, in virtue of the election," which allegedly "incorporate themselves with the constitution, and afterwards are to be regarded and expounded as parts of the instrument!"161 Clay urged that no one should doubt, however, that Jackson had even violated those duties entrusted to him by the laws-he had vetoed a bill on grounds not permitted by constitutional practice, and he had seized from the Secretary of the Treasury the duties entrusted to him by Congress. Clay ended his appeal to the Senate with the claim, again repeated against Presidents ever since, that tyranny was on the horizon. "The premonitory symptoms of despotism are upon us," Clay

159. REMINI, BANK WAR, supra note 85, at 138.

160. Id.

161. Id. 
declared, "and if Congress do[es] not apply an instantaneous and effective remedy, the fatal collapse will soon come on, and we shall die-ignobly die-base, mean, and abject slaves; the scorn and contempt of mankind; unpitied, unwept, unmourned!"162

Perhaps Clay's rhetoric goes unmatched in the attacks on the Presidency today; perhaps not. It had a profound effect upon the Senate. Webster and Calhoun followed with speeches that stretched for days. ${ }^{163}$ The Senate eventually responded by using its constitutional powers to attempt to check Jackson. Although without any legal effect, it enacted a resolution rejecting Taney's report of the reasons for withdrawal of the funds by twenty-eight to eighteen. On March 28, 1834, it passed the censure of Jackson by twenty-six to twenty. 164

Jackson cared above all about his honor, which was stung by the censure. He did not shrink away nor seek compromise. A few days after the censure, he responded with his "Protest," which remains one of the most forceful declarations of presidential power in American history. $165 \mathrm{He}$ first attacked the Senate for acting without power because it had neither enacted legislation nor initiated impeachment proceedings; the Constitution spoke nowhere of a power to censure. But his message went further in charting an expansive vision of the Presidency. He claimed the right as Chief Executive, to use his powers to attack threats to the health of the nation. "So glaring were the abuses and corruptions of the bank," Jackson wrote, "so palpable its design by its money and power to control the Government and change its character, that I deemed it the imperative duty of the Executive authority" to check the bank. ${ }^{166}$ The censure was no less than an effort by the Senate to interfere

162. Id. at $138-39$.

163. Id. at 140 .

164. 10 REG. DEB. 1187 (1834).

165. Andrew Jackson, Protest (Apr. 15, 1834), in 3 Messages AND PAPERs OF THE PRESIDENTS 69 (James D. Richardson ed., 1896) [hereinafter Jackson, Protest]. See Steven G. Calabresi \& Christopher S. Yoo, The Unitary Executive During the First Half-Century, 47 CASE W. RES. L. REv. 1451, 1545-55 (1997).

166. Jackson, Protest, supra note 165, at 85. 
with and even seize this executive authority. Each branch, however, was equal to and independent of the other, and could not interfere with the allocation of powers by the Constitution.

Having decided that the Bank was a threat, Jackson argued that he was entitled to his constitutional authorities to pursue his policies.167 Those powers included the authority to order and, if necessary, fire subordinates such as Duane. The Constitution's grant of the executive power to the President, and his duty to execute the laws, made him "responsible for the entire action of the executive department." 168 . Therefore, "the power of appointing, overseeing, and controlling those who execute the laws-a power in its nature executive-should remain in his hands."169 If a subordinate would not obey the President's orders, the President had every constitutional right to fire the subordinate and replace him with someone who would. These subordinates included the Secretary of the Treasury, regardless of what duties were delegated to the department by Congress.

The third piece of Jackson's theory of the Presidency was to link his duty to protect and his constitutional power to enforce with his role as representative of the people. Jackson declared, not for the first or last time: "The President is the direct representative of the American people."170 Through their selection of a President, the American people held the executive branch accountable. This required that Jackson have full control over every executive branch official and the enforcement of all federal law. Otherwise, there is "no direct responsibility to the people in that important branch of this Government."171 If the Treasury Secretary could reject a presidential order, it would allow him to defy "the Chief Magistrate elected by the people and responsible to them." 172 An independent Treasury Secretary, followed to its logical conclusion, "will be found effectually to

\footnotetext{
167. Id. at 85-86.

168. Id. at 79 .

169. Id.

170. Id. at 90 .

171. Id.

172. Id.
} 
destroy one coordinate department of the Government, to concentrate in the hands of the Senate the whole executive power, and to leave the President as powerless as he would be useless-the shadow of authority after the substance had departed." 173

Jackson effectively claimed a role not unlike that of the ancient Roman tribunes, implying that the President had a superior tie to the people. In perhaps the first example of a now common presidential practice, Jackson directed his message over the heads of Congress to the people. He claimed that he was only carrying out the wishes of democracy against the conspiracies of the aristocracy to hoard power. Jackson, however, was going beyond the vision of the Presidency held by Washington and Jefferson. Washington thought of himself as a republicanized monarch, and Jefferson as a prime minister. In both visions, the President was independent of Congress, but it was also coordinate-the Presidency relied upon a symbiotic relationship with the legislature for progress. Jackson's Protest was the Presidency's declaration of independence. Although each branch was independent of the other, the Executive was no longer just an equal. He was superior in his direct ties to the American people. Rather than seek legislation from Congress, Jackson's Presidency would speak for the people and force Congress to cooperate with his agenda. The President, not Congress, would dictate the tempo of politics, the focus for legislation, and represent the will of the people.

Whigs in the Senate understood what Jackson was about, and they reacted with anger. Webster argued that the President did not hold all of the executive power, he did not enjoy a removal authority, and he did not control the cabinet secretaries. But he reserved his strongest attack for the plebiscitary Presidency. Jackson believed his claims of presidential power were "enough for a limited, restrained, republican government! An undefined, undefinable, ideal responsibility to the public judgment!"174 "The

173. Id. at 86 .

174. REMINI, BANK WAR, supra note 85 , at 145. 
Constitution," Webster declared, "nowhere calls him the representative of the American people; still less their direct representative." 175 Why else, Webster asked, was the President chosen by the Electoral College rather than by direct ballot?176 If Jackson were right, Webster exclaimed, "then I say, Sir, that the government (I will not say the people) has already a master."177 Calhoun spoke even more strongly, exclaiming "[w]hat effrontery" and "boldness of assertion" from Jackson.178 "Why, he never received a vote from the American people," but only from electors.179 Calhoun predicted that Jackson would appeal to the people again to wage "hostilities" against the Senate. ${ }^{180}$ Urging that the Senate refuse to accept the Protest, Clay again prophesized the coming dictatorship. According to Jackson, "every thing concentrates in the president. $\mathrm{He}$ is the sole Executive; all other officers are his agents, and their duties are his duties." 181 This claim, Clay declared, "is altogether a military idea, wholly incompatible with free government." 182 The Senate voted twenty-seven to sixteen to reject Jackson's Protest, and then used its confirmation power over appointments to fight back. 183 It refused to confirm Jackson's nominees to the Bank's board of directors and, to put the icing on the cake, refused to confirm Taney as Treasury Secretary. 184

Jackson, however, would not be beaten. Do what they might, Biddle, the Great Triumvirate, and the Whig party could not overcome the fact that they lacked the two-thirds majority to force a re-charter, or a return of the deposits, over Jackson's veto. Jackson called forth his political powers as well, using his

175. $I d$.

176. Id.

177. Id. at 146.

178. Id.

179. $I d$.

180. $I d$.

181. 10 REG. DEB. 1575 (1834).

182. $I d$.

183. $I d$.

184. Id. 
leadership of the Democratic Party to name anti-Bank men to important congressional positions and to focus state organizations on the war with the Bank. Biddle's decision to instigate a financial panic backfired and turned public opinion against him. In January 1834, Jackson furthered his offensive by terminating the Bank's role in paying out federal pensions to Revolutionary War veterans. 185 When Biddle refused to return the funds to the government, Jackson blamed the suspension of pensions on Biddle, a story the public was only too eager to believe.186 By spring, the President's political work bore its fruit, with the governor, legislature, and two Senators from Pennsylvania-the home state of the Bank-publicly condemning Biddle and the Bank for the panic. Other state executives quickly followed suit. Led by Polk, the House followed up with a resolution against re-charter and return of federal deposits, and launched an investigation into the Bank's role in causing the panic. Biddle made matters worse by refusing to testify or provide documents to the House investigation.187 By spring 1834, the Bank had no more rights as the special handler of federal funds, lost its popular and political support, and was blamed for the economic panic. Within the year, Jackson's victory was complete: Democrats beat the Whigs badly in the 1834 midterm elections; 188 his administration retired the entire federal debt (reducing the need for a federal bank) as of January 1835;189 the Senate voted to remove the censure resolution from its books; 190 and Roger Taney was confirmed as Chief Justice upon John Marshall's death in 1835.191 Jackson reveled in his victory. "I have obtained a glorious triumph," he wrote to a friend. 192 The House's support "put to death, that mamouth [sic] of corruption

185. REMINI, BANK WAR, supra note 85 , at 160 .

186. Id.

187. Id. at 167.

188. Id. at 168 .

189. WILENTZ, supra note 1 , at 114.

190. REMINI, BANK WAR, supra note 85, at 174.

191. See WILENTZ, supra note 1 , at 150 .

192. REMINI, BANK WAR, supra note 85, at 166. 
and power, the Bank of the United States."193

Controversy has surrounded Jackson's actions ever since. There is a good case to be made that his campaign against the Bank may have contributed to the boom-and-bust swings of the American economy in the following decades. There is little doubt that a sophisticated market economy needs a central bank. Without one, politicians will be subject to the temptation to increase the money supply, which will in turn increase inflation and appeal to the part of the population that owes debts. The problem for many developing economies is keeping politics out of the bank. The problem for Jackson, however, was to keep the Bank out of politics. He had to take on the Bank, because it had become a renegade institution that used its special economic position to interfere in political elections. It was as if today's Chairman of the Federal Reserve, Ben Bernanke, put Senate Majority Leader Harry Reid on the payroll and funded John Kerry's 2004 presidential campaign. Jackson's greatness did not come from destroying a crucial part of America's financial architecture, but in fighting an agency of the federal government that was trying to control the political process for its own benefit. It would have been impossible for Jackson to prevail had he not exercised his constitutional powers of the veto, removal, and law enforcement against the wishes of Congress.

\section{THE TARIFF}

Jackson's other great achievement again drew upon his constitutional powers, but not in defense of the Presidency. Instead, he drew upon the power of his office to protect the Union. Early indications would not have placed Jackson in the camp of nationalists. With regard to Indians, Jackson ended plenary federal control over policy and recognized the right of the states to regulate. In his veto of the Bank, as well as several improvements bills, Jackson followed a limited view of federal powers which outdid even Jefferson in devotion to strict

193. $I d$. 
construction. But when Jackson saw the rising threat of secession, he did not hesitate to stretch the powers of his office to their furthest extent to preserve the Union. 194

The threat came from the small state of South Carolina, which opposed national tariff rates. Like the national bank, the political importance of the tariff may be difficult to grasp today. The Federal Reserve has placed the Bank's significance beyond question, but the tariff is most noticeable today for its absencethe success of the American-supported GATT, NAFTA, and WTO agreements has rendered the tariff a rather trivial matter. But in antebellum America, the tariff was an issue over which some were willing to die and others to break up the Union. Southerners deeply opposed the Tariff of 1824, which enacted steep duties on manufactured imports. ${ }^{195}$ It was promoted by Clay as part of his "American System" to protect domestic manufactures and promote internal improvements such as roads and canals. ${ }^{196}$ The tariff hit the South's economic interests hard; planters had to export raw material, primarily cotton, into the competitive world market, but had to purchase finished products in the home market where tariffs kept prices high. Some southerners believed the Constitution prohibited taxation for purposes other than raising revenue, and that one part of the nation-the North-could not benefit from taxes at the expense of another. In 1828, a bill that raised rates became known in the South as the "tariff of abominations" and sparked secessionist rallies in several Southern cities. 197

South Carolinians rallied around the idea of "nullification." Developed in secret by Calhoun, nullification maintained that the states each retained their independent sovereignty and that the

194. For historical background on the political and economic issues surrounding the tariff, see HOWE, supra note 1, at 395-410; RICHARD ELLIS, THE UNION AT RISK: JACKSONIAN DEMOCRACY, STATES' RIGHTS, AND THE NULLIFICATION CRISIS (1987).

195. See WILENTZ, supra note 1 , at 63 .

196. See id.

197. Id. 
Constitution was an agreement between them.198 No single American people created the Constitution as their governing document. Majority rule through the Constitution could not override state sovereignty. If a majority imposed an unconstitutional law on a single region, a state could "nullify" the federal law within its borders. Historians argue about the origins of nullification, but there can be little doubt that it strongly echoes Jefferson's claim, made in the Kentucky Resolves, that a state could oppose the implementation of the Alien and Sedition Acts. Calhoun similarly believed that South Carolina could refuse to enforce an unconstitutional tariff while it sought redress through the national political process. If those efforts failed, Calhoun believed, a state could consider secession. South Carolina adopted a legal brief defending nullification, secretly drafted by Calhoun and published as the South Carolina Exposition and Protest. 199 Its simple conclusion was that states possessed the sovereignty to veto actions of the federal government.

This question prompted one of the greatest debates ever to occur in the Senate-between Webster and South Carolinian Robert Hayne.200 After Hayne argued in favor of a state sovereignty independent of the Constitution, Webster gave his well-known speech defending the importance of the Union. It ended with the famous words, "Liberty and Union, now and forever, one and inseparable." 201 Jackson made his own views clear on nullification at a political banquet in honor of Thomas Jefferson in April 1830, at which both Jackson and Calhoun

198. See id. at 63-64.

199. John C. Calhoun, Exposition and Protest (Dec. 19, 1828), in UNION AND Liberty: The Political Philosophy of John C. Calhoun (Ross M. Lence ed., 1992).

200. It is difficult to escape the conclusion that the real issue behind nullification was not the tariff, but slavery. If a numerical majority in the North could enact a tariff over Southern objections, Southerners asked, what would prevent it from eradicating slavery too.

201. Daniel Webster, Speech on Mr. Foot's Resolution, in 2 AMERICAN ELOQUENCE: A COLLECTION OF SPEECHES AND ADDRESSES BY THE MOST IMMINENT ORATORS OF AMERICA 899 (Frank Moore ed., 1857). 
appeared. Held by Southern and Western Congressmen opposed to the tariff, Jackson had come ready to take on nullification and was already nearing the break with Calhoun. Several preselected speakers gave increasingly inflammatory toasts in favor of state sovereignty. When the President's turn came, all became silent to see what position he would take. As always, Jackson left no doubt about where he stood. "Our Union," he declared, "it must be preserved." 202 Calhoun followed. In the midst of a rambling toast, the Vice President responded "The Union, next to our liberty the most dear. May we all remember that it can only be preserved by respecting the rights of the States, and distributing equally the benefit and burden of the Union."203

Jackson had declared war on nullification. Although perhaps in conflict with his views on the Bank and internal improvements, his defense of the Union made sense because of his elevation of democracy as his guiding principle. If the majority of the people spoke through their elected representatives, he believed, a state had no right to frustrate their will. The Union had been the product of the Revolution, in which Jackson had risked his life as a young boy, and to which he had lost his mother and brother. He was not about to see it broken by a state, even the state of his birth. "There is nothing I shudder at more than the idea of the separation of the Union," he wrote in 1828.204 Although he firmly believed that the powers of the federal government were limited and that the states were to exercise all others not granted, Jackson believed even more so in the permanency of the Union. State sovereignty could not become an excuse for secession.

Jackson hoped to reach a compromise as the election of 1832 neared. Without admitting the legitimacy of the South's grievances, he successfully urged Congress to enact a new bill that reduced tariffs. The national debt was being steadily reduced, and soon the revenue from the tariff would no longer be

202. WILENTZ, supra note 1 , at 65 (emphasis added).

203. JAMES PARTON, LIFE OF ANDREW JACKSON 283 (1888).

204. WILENTZ, supra note 1 , at 64 . 
needed. A mere month after Jackson won reelection, South Carolina responded by holding a convention that declared the 1832 law void, and threatened secession should the government enforce it. Jackson responded with a two-front strategy, one political and one constitutional. In his Annual Message to Congress on December 4, 1832, Jackson offered a political compromise. Tariff protections "should not exceed what may be necessary to counteract the regulations of foreign nations and to secure a supply of those articles of manufacture essential to the national independence and safety in time of war."205 There was "no reason to doubt" that domestic industry was "beneficial to our country," and he acknowledged that "large capital" had been invested in reliance on the tariff. Nonetheless, investors and producers had no right to expect "that the people will continue permanently to pay high taxes for their benefit, when the money is not required for any legitimate purpose . . ."206 In a nod to South Carolina, Jackson also criticized a high tariff as tending "to beget in the minds of a large portion of our countrymen a spirit of discontent and jealously dangerous to the stability of the Union."207 He proposed that Congress study a gradual reduction of rates. 208 To Jackson, the policy issue-how high tariff rates should go-was always open for bargaining.

The Union, however, was non-negotiable. Jackson made this clear six days later with an extraordinary proclamation. He drew on his constitutional powers "for preserving the peace of the Union and for the execution of the laws" to suppress nullification.209 The American people, he said, spoke as one in electing the President; the Presidency, not the legislature,

205. Andrew Jackson, Fourth Annual Message to Congress (Dec. 4, 1832), in 2 Messages and Papers of the Presidents 598 (James D. Richardson ed., 1896).

206. Id.

207. Id.

208. $I d$.

209. Andrew Jackson, Proclamation (Dec. 10, 1832), in 2 MESSAGES AND PAPERS OF THE PRESIDENTS 641 (James D. Richardson ed., 1896) [hereinafter Jackson, Proclamation]. 
represents the people as a whole.210 On behalf of the nation, Jackson left no doubts about his position on nullification. Nullification was "incompatible with the existence of the Union, contradicted expressly by the letter of the Constitution, unauthorized by its spirit, inconsistent with every principle on which it was founded, and destructive of the great object for which it was formed." 211 He made short work of South Carolina's criticism of the tariff laws. He denied that a state could pick and choose which federal laws to enforce. Even if the Supremacy Clause had not expressly provided for the superiority of federal law, it was inherent in the creation of the federal system where the central government received exclusive authority over enumerated subjects. "Our Constitution does not contain the absurdity of giving power to make laws and another to resist them." 212 If a single state could block federal law, the Constitution was useless. "Vain provisions! ineffectual restrictions! vile profanation of oaths! miserable mockery of legislation!"213

It was no defense to claim that the tariff affected one region more than another. Every law impacts states and regions differently. On a point dear to him, Jackson suggested that the War of 1812 would have had a different outcome had states nullified laws that impacted them unequally - a veiled reference to the talk of secession that had swept New England when the war went badly. ${ }^{214}$ It did not matter that Congress wanted to spend the money on unconstitutional projects, such as internal improvements, which Jackson himself had vetoed. What mattered was whether Congress's act in passing the tariff was constitutional, not whether its motive was.

For Jackson, the question boiled down to what came first, the states or the nation. Only if the Constitution was merely a

210. 3 REMINI, JACKSON, supra note 1 , at 21.

211. Jackson, Proclamation, supra note 209, at 643 (emphasis in original).

212. Id. at 645 .

213. Id. at 646 .

214. Id. at 642 . 
league, and the nation just an agreement of the states, could a state choose to withdraw or change the terms of the contract. But if the United States were a nation, representing the people directly, no state could set itself apart from the Union and its laws. For the general who had risked his life as a boy in the first war of independence, and who stopped a British invasion in the second, the answer was clear. Even before the Declaration of Independence, Jackson observed, "we were known in our aggregate character as the United Colonies of America," and "[w]e declared ourselves a nation by a joint, not by several acts . . ."215 The states had transferred parts of their sovereignty over issues such as war and peace to the federal government, and the allegiance of their citizens to the nation. No state could place itself above that act of union. Nullification was merely a "[m]etaphysical subtlety, in pursuit of an impracticable theory," actually designed to destroy the Union by forcing the nation to depend on the goodwill of individual states. 216

Nullification struck at the very heart of Jackson's program, the defense and expansion of majoritarian democracy. "The Constitution of the United States," he wrote in the Proclamation, "forms a government, not a league ...."217 In that government, "all the people are represented," and it "operates directly on the people individually, not upon the States . . ."218 Because of this direct link between the people and the Union, the national government and its leaders could not arbitrarily choose to ignore the Constitution and give up powers to the states, nor could it allow a state to fence itself off from federal law. "[S] uch secession does not break a league, but destroys the unity of a nation; and any injury to that unity is not only a breach which would result from the contravention of a compact, but it is an offense against the whole Union."219 Secession, which Jackson believed was the real movement behind nullification, directly contradicted

\footnotetext{
21.5. Id. at 643 .

216. $I d$.

217. Id. at 648 .

218. $I d$.

219. Id.
} 
American nationhood. "To say that any State may at pleasure secede from the Union is to say that the United States are not a nation."220 As Remini observes, Jackson was the first major American statesman to argue that the Union was a perpetual entity.221 Lincoln would owe much to Jackson's theory of the Constitution, the Presidency, and the Union.

Jackson's conclusion followed his strategy of seeking political accommodation while preparing for legal and even military confrontation. He appealed to South Carolina's citizens to put aside thoughts of disunion. Jackson addressed them as "[f]ellowcitizens of my native State." They were being deluded by their leaders, and he warned them as "a father would over his children whom he saw rushing to certain ruin." 222 He appealed to their patriotism: "Carolina is one of these proud States; her arms have defended, her best blood has cemented, this happy Union."223 But Jackson left no doubts about what would happen if South Carolina did not compromise. "Disunion by armed force is treason." 224 No one needed a refresher on what Jackson had done to the enemies of the United States. He would use all of his constitutional powers to prevent nullification or secession. "The laws of the United States must be executed," Jackson declared.225 "I have no discretionary power on the subject; my duty is emphatically pronounced in the Constitution."226 The President left little doubt that he would resort to military force if need be. "On your unhappy State will inevitably fall all the evils of the conflict you force upon the Government of your country."227 Jackson promised that their defeat was certain.

[The Constitution's] destroyers you can not be. You may disturb its peace, you may interrupt the course of its

220. Id.

221. 3 REMINI, JACKSON, supra note 1, at 22.

222. Jackson, Proclamation, supra note 209, at 652 .

223. Id. at 654.

224. Id.

225. Id.

226. Id.

227. Id. at 654-55. 
prosperity, you may cloud its reputation for stability; but its tranquility will be restored, its prosperity will return, and the stain upon its national character will be transferred and remain an eternal blot on the memory of those who caused the disorder. 228

More vigorous and aggressive words have never left a President's pen.

Jackson's proclamation was greeted with widespread support throughout the country, but left South Carolina unmoved. $\mathrm{He}$ kept the pressure up through statements in the press attacking nullification and defending the perpetual Union. Jackson moved to cut off South Carolina politically, while preparing for military action. Three days after Jackson's proclamation, South Carolina's Governor resigned to lead the state's militia; he was replaced by Senator Hayne. Calhoun was selected by the legislature to enter the U.S. Senate. Twenty-five thousand South Carolinians volunteered to fight. The legislature authorized the governor to call out the militia and to begin a draft, and appropriated $\$ 250,000$ for arms.229 Jackson sent military troops and a naval vessel to reinforce the federal bases in Charleston harbor. He ordered the War Department to prepare three divisions of artillery to move against the state the moment South Carolina's legislature acted to carry out nullification. ${ }^{230}$ In a letter to a Union supporter in the state, Jackson promised that the moment South Carolina used force, he would "call into the field, such a force as will overaw[e] resistance, put treason and rebellion down without blood" and arrest those guilty of treason and rebellion.231 Jackson planned for 10,000 to 15,000 federal troops to occupy Charleston within two weeks of an outbreak of violence, and drafted an order calling up the military to defend the Union. 232

228. Id. at 655 .

229. 3 REMINI, JACKSON, supra note 1 , at 26.

230. Id.

231. Id. at 34 .

232. Id. 
But rather than use military force immediately, Jackson turned to Congress. Jackson preferred to leave military action as a last resort, and instead wanted Congress to authorize law enforcement officials to execute the customs laws and arrest traitors. Congressional action would slow down the rush to a confrontation and serve as a forum to further isolate South Carolina politically. Jackson recognized that if he acted unilaterally, he "would be branded with the epithet, tyrant." 233 He extended an olive branch on January 8,1833 by proposing to return tariffs to their 1818 levels. At the same time, Jackson responded to South Carolina's military preparations by requesting a Force Bill. Jackson informed Congress that he would continue the collection of federal customs in the port of Charleston, and would move the location of the Customs House to a more defensible fort, which had the effect of placing South Carolina in the position of firing the first shot. He wanted Congress to delegate broad authority to relocate these federal offices, some technical changes to expand the jurisdiction of the federal courts in the area, and a change in the Militia Act (the same used by Washington and Jefferson) to allow him to immediately call federal forces into action when federal law was obstructed without the need for a proclamation. He labeled South Carolina's actions as "revolutionary in their character and tendency, and subversive of the supremacy of the laws and of the integrity of the Union," a "usurpation of power," and a threat to the "liberties and happiness of the millions composing this Union."234 He closed by making clear, once again, that the Union represented the people, he acted on behalf of that people, and that a small minority could not secede from it. The Framers "bequeathed to us a Government of laws and a Federal Union founded upon the great principle of popular representation." 235 Jackson was called upon to discharge the duty of protecting the

233. Id. at 29.

234. Andrew Jackson, Message to Congress (Jan. 16, 1833), in 2 Messages AND PaPERs of the PRESIDENTS 620-21 (James D. Richardson ed., 1896).

235. Id. at 631 . 
Union. Congress must act to "solemnly proclaim that the Constitution and the laws are supreme and the Union indissoluble." 236 Going beyond appeals to sentiment and patriotism, Jackson presented a robust theory about the origins of the Union and the Constitution that would set an important precedent for Lincoln and other Chief Executives.

The Force Bill conveyed no real authority that Jackson did not already have, but served as a call for political support from Congress should military action become necessary. Jackson's willingness to make a deal on the tariff, combined with a display of indomitable will on the constitutional issue, produced a political resolution. Congress remained the only national forum where different regional interests could work out a bargain, and it held the constitutional authority over tariff rates. South Carolina postponed nullification while the Senate debated the force and tariff bills. With the rare spectacle of Clay supporting the Jackson administration, the Senate passed the Force Bill after the few supporters of nullification left the Senate chamber in protest.237 Clay then reached a bargain with Calhoun, in which the former supported a reduction in rates in exchange for the latter's guarantee that South Carolina would repeal its nullification law. No Force Bill would be required. Jackson's "promise" of war had convinced South Carolina's representatives to give way.238 The Clay-Calhoun tariff passed quickly at the same time as the Force Bill, which received an overwhelming one hundred vote majority in the House-a demonstration of Jackson's success in politically isolating South Carolina, not just in the North and West, but in the South.

Historians consider Jackson's victory in the nullification fight his greatest achievement as President. He stopped a movement to undermine the supremacy of federal law which could have brought secession three decades early. Although he threatened to resort to the military to enforce federal law, he kept pushing

236. Id. at 632 .

237. 3 REMINI, JACKSON, supra note 1 , at 37.

238. Id. at 38. 
for a political solution that would avoid conflict. His overall policy preserved the Union. Jackson could not have reached this result without a broad vision of his duty to enforce the law, of his power as Chief Executive and Commander-in-Chief, and of his role as representative of American democracy. He used this robust understanding of the Presidency to pursue his understanding of the United States as a Union of one people. A President with a smaller conception of the office, like some of his successors, might have disclaimed any role in settling the issue of secession-after all, there is no enumerated power in the Constitution giving the President the authority to settle political disputes between the regions-and allowed South Carolina to go its own way. Jackson's genius was to harness the theory of one Union and one American people to the rising forces of democracy. But he could not have succeeded without a broad understanding of his constitutional powers and the willingness to use them.

\section{CONCLUSIONS}

Jackson reconstructed the Presidency. His tenure in the office was every bit as revolutionary as that of Washington or Jefferson. He did not restore the office by breaking its constitutional limits, as critics claimed, but by fulfilling the broadest visions of its designers. Jackson broke Congress's control and established the Presidency as the co-equal, competing voice of the people's wishes. The people, not Congress, would select the President. It would be the people, not Congress, whom Jackson represented. Critical to re-asserting the Presidency's independence was Jackson's declaration of the right to interpret the Constitution for himself, rather than defer to the Supreme Court or Congress. In making the Presidency the primus inter pares of the national government, Jackson drew upon the other powers of his office, including control over the execution of the law, removal of subordinates, and, of course, the veto pen.

At times, Jackson's exercise of the Presidency's constitutional powers produced results that many would not agree with today. Jackson almost single-handedly conquered Florida for the United States and set the stage for Texas's annexation, but he did so 
without legislative approval and support. While removing the influence of the Bank from politics, Jackson's war against Biddle rejected the benefits of a national banking system. A central bank, properly managed, could have smoothed out the boom-andbust cycles of the American economy in the decades to come. The creation of the Federal Reserve Bank would have to wait until Woodrow Wilson. Removal of the Indians allowed for broader settlement of the Southwest, but it visited untold suffering on the Cherokee and other tribes. His strong faith in American expansionism did not include a place for Indians, and the results of his policies remain one of the terrible examples of the nation's mistreatment of its own people.

Jackson's exercise of the powers of his office did not go without criticism and opposition. Like other Presidents who have made broad claims of executive authority, Jackson was attacked as a tyrant or dictator. Congress attempted to use its powers to oppose Jackson, going so far as the only censure of a President in American history, but the people sent Jacksonian majorities to Congress that reversed these efforts. Nonetheless, Jackson's use of presidential power sparked a seismic political response, the creation of the Whig political party whose platform centered on executive restraint. Opposition to Jackson's use of presidential power restored the two party political system to America.

Despite these negative aspects to his time in office, scholars continue to regard Jackson as one of the ten greatest presidents. His foreign policy expanded the frontiers of the nation and opened land to economic development. Expansion did not trigger the centrifugal forces of nullification. Jackson exercised the full powers of his office to protect the Union and the supremacy of federal law against the birth of secessionism. He democratized the political system by ending the corruption of the Bank, turning out long-time officeholders, and opening up politics to the rising South and West. He reestablished the Presidency as an independent center of power that could pursue policies in the national interest, even if at odds with congressional wishes. $\mathrm{He}$ could not have achieved any of the positives of his Presidency 
without a reinvigorated understanding of the constitutional powers of the office. And he bequeathed to a future President, Abraham Lincoln, an understanding of the office that allowed him to save the Union when secession came.

Jackson's restoration of the constitutional powers of the Presidency reached its apogee under his protégé, James K. Polk. Scholars also consider Polk to be one of history's ten greatest Presidents, and today he is ranked even above his former mentor. Polk had served as speaker of the House during the Jackson administration and was later elected governor of Tennessee. When the leading candidates for the 1844 election, Van Buren for the Democrats and Clay for the Whigs, both announced they would not support the annexation of Texas, Polk went the other way with Jackson's blessing. Supporters of expansion at the Democratic convention blocked Van Buren's nomination, and Polk emerged as the dark horse candidate. He sought to unify the Democratic party by promising to serve only one term. Whigs campaigned on his relative obscurity by asking "Who is James K. Polk?" They received their answer when Polk won on the platform of annexing Texas, occupying all of the disputed Oregon territory (which would have included parts of Canada between the contemporary borders of Washington state and Alaska), and acquiring California. Polk prevailed in a close election with 1.337 million votes to Clay's 1.299 million, but by a larger electoral college advantage, 170 to 105.239

Polk interpreted his election as a popular mandate, building on Jackson's example of the President as the tribune of the people. ${ }^{240}$ Polk in particular coveted California's fine harbors at San Francisco and San Diego, which would aid American merchants and provide the hemisphere's finest ports for the navy. The mandate for expansion was so evident that his predecessor, John Tyler, used his lame-duck months in office to engineer the annexation of Texas-and in a manner that further (1987)

239. See generally Paul Bergeron, The Presidency of James K. Polk 1-21

240. Id. at 20 . 
[Volume 2

enhanced presidential power. Anti-slavery Democrats and Whigs in the North had successfully blocked proposals to annex Texas by treaty. With Polk's support, Tyler simply turned about and asked Congress to incorporate Texas by statute, which required a simple majority in both houses. ${ }^{241}$ The use of a statute rather than a treaty would set a precedent for future presidents, who would resort to what would become known as congressionalexecutive agreements to adopt the Bretton Woods agreement or the General Agreement on Tariffs and Trade.

Annexation of Texas almost guaranteed a confrontation with Mexico, with which it shared an uncertain border. At first attempting diplomacy, Polk sent envoys to purchase California and the southwest territories. John Slidell, who would later pursue another failed diplomatic mission on behalf of the Confederacy, got nowhere.242 Even though Mexico was bankrupt and had few settlers or troops in the territories, its leaders uniformly viewed the sale of their northern territories as dishonorable and refused to negotiate. 243 Polk decided to turn to military means, especially after rumors arrived that Mexican forces were reinforcing California with British financial support. In early 1846, the President ordered General Zachary Taylor to move his forces of 1,500 troops into the disputed territory between Mexico and Texas. 244 Texas claimed that its territory had reached as far south as the Rio Grande River, though as a Mexican province and an independent state its control had never extended beyond the Nueces River (about 150 miles farther north from the Rio Grande). Most historians agree that Texas had little claim to the Rio Grande border, but Polk was determined to defend it with military force. He paired his efforts to create a provocation in Texas with preparations to seize California. Polk ordered naval units to be prepared to seize San Francisco in the event of war. Army captain John Fremont, already in California,

241. Id. at 54-56.

242. Id. at 69-72.

243. Id. at 70 .

244. Id. at $62-63$. 
took a page from the Texas script and began to encourage American settlers to revolt. 245

Polk and his cabinet had decided to go to war even before these plans in Texas and California had come to fruition.246 But on April 25, 1846, the desired skirmish occurred between Taylor's patrols and Mexican forces.247 Taylor had moved all the way to the Rio Grande directly across from superior Mexican forces, and blockaded them. The surrounded Mexican troops tried to fight their way out, with the loss of eleven Americans. Taylor attacked the superior Mexican forces and defeated them in two battles on May 8th and 9th. Two days after the news of the first skirmish arrived in Washington, Polk sent a war message to Congress. It misrepresented the facts to guarantee the majorities for war. Polk claimed that he had deployed troops on the U.S. side of the disputed territory and had ordered them to assume a purely defensive posture. He asserted that Mexican forces had fired the first shot in an offensive move onto American territory. "Mexico has passed the boundary of the United States, has invaded our territory, and shed American blood on American soil," Polk told Congress. 248 In fact, "war exists, and, notwithstanding all our efforts to avoid it, exists by the act of Mexico herself," Polk declared.249 He called upon Congress "to recognize the existence of the war, and to place at the disposal of the Executive the means of prosecuting the war with vigor, and thus hastening the restoration of peace." 250

Polk had used his control over the military to create a situation that had triggered a state of war. He could even have argued that he had the inherent constitutional authority to wage war without congressional cooperation, because of Mexico's

245. Id. at $72-73$.

246. Id. at 75-76.

247. Id.

248. James K. Polk, To the Senate and House of Representatives (May 11, 1846), in 5 Messages and Papers of the Presidents 1789-1897, at 442 (James D. Richardson ed., 1896).

249. Id.

250. Id. at 443 . 
attack. But he could not conduct significant offensive operations against another nation without congressional authorization of a new army of 50,000 and $\$ 10$ million in funding. Polk's demand for support opened a sectional divide in Congress that organized itself along partisan lines. Whigs in the North opposed the war, which they viewed as an effort to expand the territory open for slavery; it had become an article of faith in both the North and South that slavery would perish if it could not expand. Democratic leaders in the South and West overwhelmingly supported the war, except Calhoun, who worried that the addition of California and New Mexico as free states outweighed the benefits for slavery in Texas. Approval for the recognition of a state of war with Mexico prevailed in test votes by 123 to 67 in the House, and 26 to 20 in the Senate. After heavy political pressure from the White House, the final declaration of war was attached to the funding and army bills and was approved with only fourteen 'opposing votes in the House and two in the Senate. Whigs read public opinion as showing a strong majority in favor of more territorial expansion, and made no serious effort to stop the war. They continued to vote in favor of supplies for the troops, while continuing to denounce Polk for starting the conflict. But the conflict first opened up not just a dangerous division between North and South, but aligned it with the two political parties. 251

Once war began, Polk took firm command of its operations. California fell quickly to a remarkably small force of American settlers and regular Army and Navy forces. He dispatched a small force to the New Mexico territory, which also quickly capitulated. Taylor's army of 4,500 won a series of battles in northern Mexico, capturing Monterey in late 1846. His campaign culminated in the January 1847 Battle of Buena Vista, where he defeated Santa Anna's army of 20,000. Despite these military successes, the war was not as easy and swift as Polk and his advisors had anticipated. Mexico had rejected peace overtures, and Mexican forces had put up stiff resistance in the North.

251. Howe, supra note 1 , at 731-91. 
They realized that Mexican politics would not permit a negotiated settlement of the war. They decided to seek a more absolute victory. A drive to Mexico City from the North was impractical because of inhospitable terrain. Polk decided on a risky amphibious landing at Veracruz on the Gulf of Mexico, to be followed by a land advance to the Mexican capital. He had the good sense to place in command Winfield Scott, who executed one of the most successful American military campaigns in history. With 10,000 troops, he captured the heavily defended Veracruz in March 1847, twice defeated larger armies led by Santa Anna, and captured Mexico City on September 14. The Mexican government surrendered and General Scott imposed an occupation government on the capital. Officers, such as Grant, Lee, Jackson, Meade, Pickett, and McClellan, would all serve in this "dress rehearsal" for the Civil War. ${ }^{252}$

Even as Polk's war plans succeeded, he came under increasing opposition at home. The 1846 elections returned a narrow anti-war Whig majority. Polk greeted the new Congress with a state of the Union message that claimed that Mexico had started the war and that the United States had only acted in selfdefense. Mexico's past wrongs against the United States and its provocation of war required an "indemnity" - namely the Southwest and California. Congress, Polk noted, approved the war, and once declared, "it became my duty under the Constitution and the laws to conduct and prosecute it."253 To Whigs who argued that the war should result in no new territory, Polk responded "the doctrine of no territory is the doctrine of no indemnity."254 If adopted, he warned, it "would be a public acknowledgement that our country was wrong and that the war declared by Congress with extraordinary unanimity was unjust

252. See generally John S.D. EISEnHower, So FAR From God: The U.S. WAR WITH MEXICO, 1846-1848 (2000).

253. James K. Polk, Third Annual Message (Dec. 7, 1847), in 5 MessaGes and Papers of The Presidents, 1789-1897, at 534 (James D. Richardson ed., 1896).

254. Id. at 538. 
and should be abandoned."255 A young Whig freshman congressman, Abraham Lincoln, rose to challenge Polk's accounting of events. He introduced a series of resolutions questioning whether the Rio Grande had ever been understood as the border of Texas, whether Mexico had started the war, and he demanded that Polk provide information to Congress on "the spot" where the first skirmish had occurred.256 In a speech on January 12, 1848, Lincoln accused Polk of starting the war and "trusting to escape scrutiny, by fixing the public gaze upon the exceeding brightness of military glory."257 Neither the House nor the President, however, seems to have paid much attention to Lincoln, though the House by 85-81 passed a resolution praising General Taylor and declaring that Polk has started the war "unnecessarily and unconstitutionally," which the Senate rejected. ${ }^{258}$

An anti-war Congress, however, could not prevent the Commander-in-Chief from continuing to dictate wartime strategy and operations. Even before the war had started, Polk had decided how American forces would be deployed and defined their objectives. After the capture of Mexico City, the President unilaterally set occupation policy, which included holding the capital, the major ports, and collecting tax revenues to offset the cost of military operations. While Polk had hoped to squeeze the Mexicans until they agreed to a favorable peace, he began to hope for broader territorial concessions. With Mexico's government weak, its military almost non-existent, and its people unruly, Polk now wanted Baja California, all of Mexico as far south as Tampico (another 500 kilometers south of the Rio Grande), and control of the isthmus of Tehuantepec for the construction of a transcontinental canal. Polk's vigorous control of the executive power also led him to unilaterally govern the process for making

255. Id.

256. David H. Donald, LinColN 122-24 (1995).

257. Abraham Lincoln, From a Speech in the United States House of Representatives on the Mexican War (Jan. 12, 1848), in THE LIFE AND WRITINGS of ABRAHAm Lincoln, at 304 (Philip Van Doren Stern ed., 1940).

258. HowE, supra note 1 , at 797 . 
peace. He chose the peace envoys without Senate advice and consent, set the goals for the negotiations, and ultimately decided to send to the Senate the 1848 Treaty of Guadalupe Hidalgo (even though his negotiator, Nicholas Trist, had only won Polk's minimum terms). While it did not encompass all of Polk's territorial ambitions, it did transfer California, the future states of Arizona, New Mexico, Nevada, and Utah, and the disputed territory on the Texas border, in exchange for the paltry sum of $\$ 15$ million. Mexico lost 40 percent of her territory, while the United States gained the land that would be the base for its future world power. ${ }^{259}$ The treaty ended the Mexican-American War on acceptable terms, without a long-term occupation or the descent into chaos along the southern border.

Political opposition during the Mexican-American War, however, also demonstrates the checks that Congress always has available against the executive, even at the height of his wartime powers. Polk had to agree to the terms of the Treaty of Guadalupe Hidalgo for a reason-Congress would not support the actions needed to conquer more land. Polk had wanted to continue pressuring the Mexicans by continuing military operations. Even after the fall of Mexico City, he had ordered American troops to invade Baja California and had proposed sending forces to annex the Yucatan peninsula. To expand military operations beyond occupation duty, the President needed more troops and more money. American forces had suffered 10 percent casualties, with seven out of every eight being lost to disease rather than battle. The costs of the war were reaching $\$ 100$ million. Congress refused. The Whigdominated Congress rejected Polk's requests for new land and excise taxes and increases in the size of the army. The Senate ratified the terms of the peace treaty by 36-14. While some Southerners wanted more land, the majority of Whigs wanted no territory other than San Francisco. Congress would not have allowed Polk to grab more of Mexico than he did.260

259. Id. at 796-811.

260. Id. 
Polk, like Jackson before him, sparked partisan opposition with his energetic exercise of presidential prerogatives. Just as Jackson's war with the Bank led his opponents to organize a new political party against him, Polk's war was followed by a Whig victory in the next presidential elections. Polk's greater success, in fact, sparked a more dangerous reaction. Support for the war resided primarily in the South and among Democrats, while opposition centered in the Northeast among Whigs. By opening a huge territory to settlement and statehood, the MexicanAmerican War had made the future of slavery the central issue of national politics. The war aligned North and South antagonism over slavery with the political parties, which would remove the ability of the partisan institutions to ameliorate sectional tensions. The volatile mixture of new territory and political inflexibility would set the conditions for the coming of the Civil War.

Even though the treaty did not recognize even broader American gains, it cemented Polk's place among the nation's greatest Presidents. Polk secured Texas and added the land between the Louisiana Purchase and the Pacific Ocean to the United States. He increased the size of the nation more than any President before or since. While these lands had been sparsely settled under their previous owners, they would someday become the most populous and dynamic states in the Union. Polk's vision not only gave the United States a continent-wide breadth, but it also neutralized any natural enemies along its northern or southern borders. With the addition of California and the Northwest, the United States would be protected on both flanks by wide oceans, and by the end of the century it would become a great power in both Europe and Asia. Today, the expansion of the United States seems inevitable, just as the propagandists for "Manifest Destiny" believed. But it was not. Polk pursued a high-risk strategy that prevailed thanks to the weakness of Mexico and the superior fighting abilities of the U.S. armed forces. 261

261. Id. at 809 . 
A President with a modest view of his constitutional powers would have shrunk from provoking war over the Texas border, not to mention invading Mexico. Only by fully exercising the powers of the Presidency, as laid down by Andrew Jackson, could Polk's determination to reach the Pacific have been realized. As Commander-in-Chief, Polk manipulated events to produce a war, maneuvered Congress into funding it, and held sole control over its goals and strategies. In the words of the leading historian of the period, Daniel Howe, Polk "probably did as much as anyone to expand the powers of the Presidency - certainly at least as much as Jackson, who is more remembered for doing it." Overcoming the errors of Madison's ways, the vigor and energy of his leadership set the model for other Presidents in wartime. Polk's success was inextricably intertwined with the Jacksonian understanding of a constitutionally energetic executive, and it worked to the nation's incalculable benefit. 262

262. Id. at 808 . 
HeinOnline -- 2 Charleston L. Rev. 584 2007-2008 